\title{
LEVEL II SCOUR ANALYSIS FOR BRIDGE 26 (JAMATH00010026) on TOWN HIGHWAY 1, crossing BALL MOUNTAIN BROOK, JAMAICA, VERMONT
}

U.S. Geological Survey Open-File Report 97-395

Prepared in cooperation with

VERMONT AGENCY OF TRANSPORTATION and

FEDERAL HIGHWAY ADMINISTRATION 


\section{LEVEL II SCOUR ANALYSIS FOR BRIDGE 26 (JAMATH00010026) on TOWN HIGHWAY 1, crossing BALL MOUNTAIN BROOK, JAMAICA, VERMONT \\ By Ronda L. Burns and Laura Medalie}

U.S. Geological Survey Open-File Report 97-395

Prepared in cooperation with

VERMONT AGENCY OF TRANSPORTATION and

FEDERAL HIGHWAY ADMINISTRATION 


\title{
U.S. DEPARTMENT OF THE INTERIOR BRUCE BABBITT, Secretary
}

\author{
U.S. GEOLOGICAL SURVEY \\ Gordon P. Eaton, Director
}

For additional information write to:

District Chief

U.S. Geological Survey 361 Commerce Way

Pembroke, NH 03275-3718
Copies of this report may be purchased from:

U.S. Geological Survey

Branch of Information Services

Open-File Reports Unit

Box 25286

Denver, CO 80225-0286 


\section{CONTENTS}

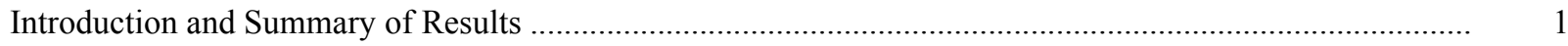

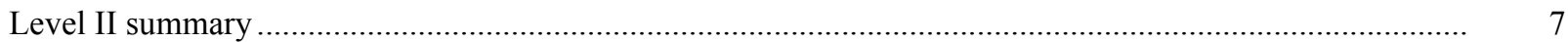

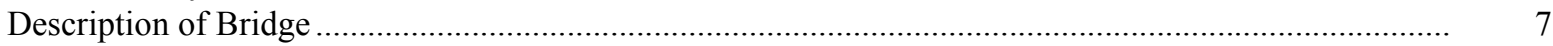

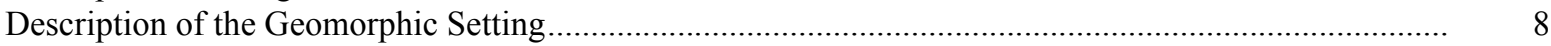

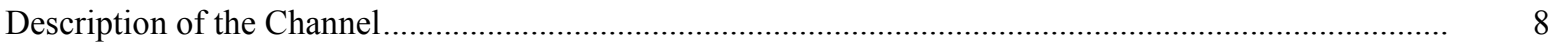

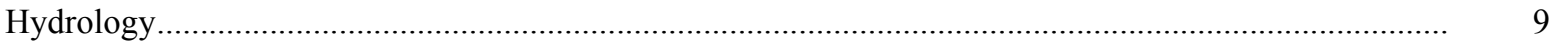

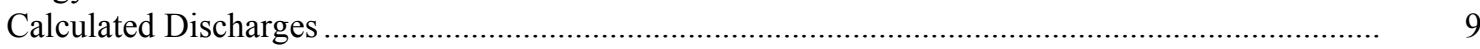

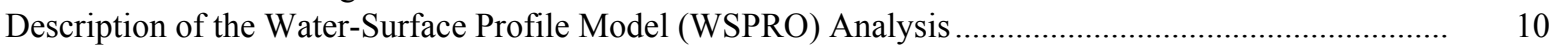

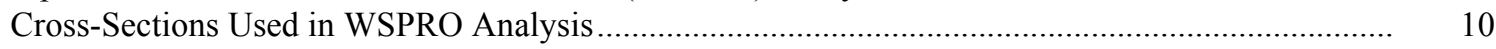

Data and Assumptions Used in WSPRO Model ...................................................................... 11

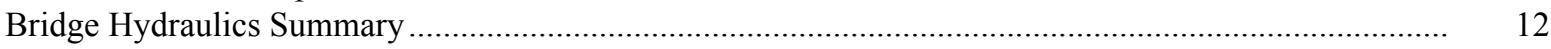

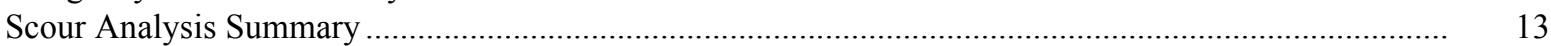

Special Conditions or Assumptions Made in Scour Analysis ...................................................... 13

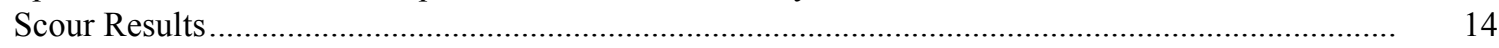

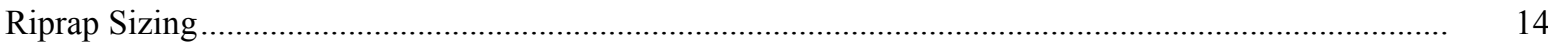

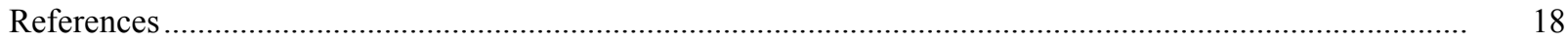

Appendixes:

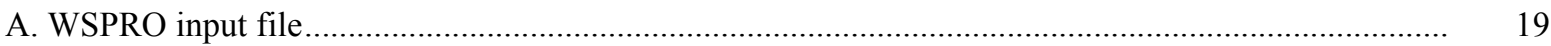

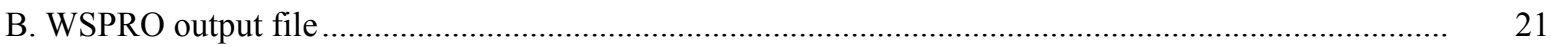

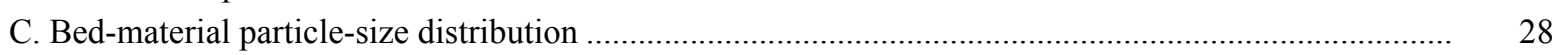

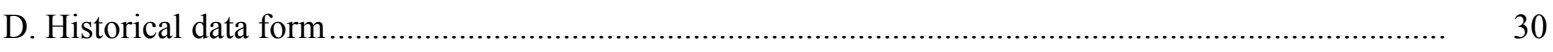

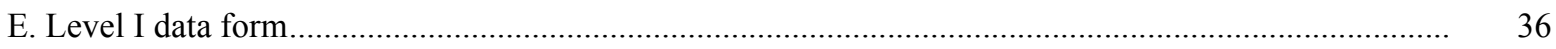

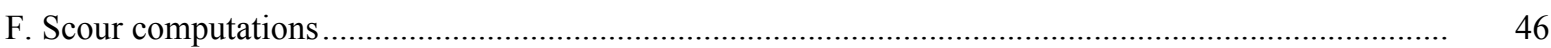

\section{FIGURES}

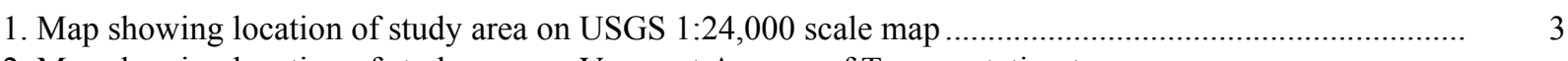

2. Map showing location of study area on Vermont Agency of Transportation town
highway map

3. Structure JAMATH00010026 viewed from upstream (August 12, 1996) .............................................. 5

4. Downstream channel viewed from structure JAMATH00010026 (August 12, 1996)............................ 5

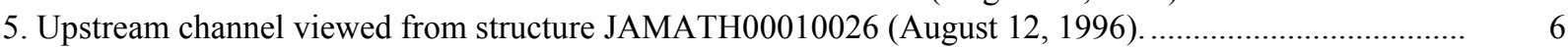

6. Structure JAMATH00010026 viewed from downstream (August 12, 1996)........................................ 6

7. Water-surface profiles for the 100- and 500-year discharges at structure JAMATH00010026 on Town Highway 1, crossing Ball Mountain Brook,

Jamaica, Vermont.

8. Scour elevations for the 100- and 500-year discharges at structure

JAMATH00010026 on Town Highway 1, crossing Ball Mountain Brook,

Jamaica, Vermont.

4

5

(




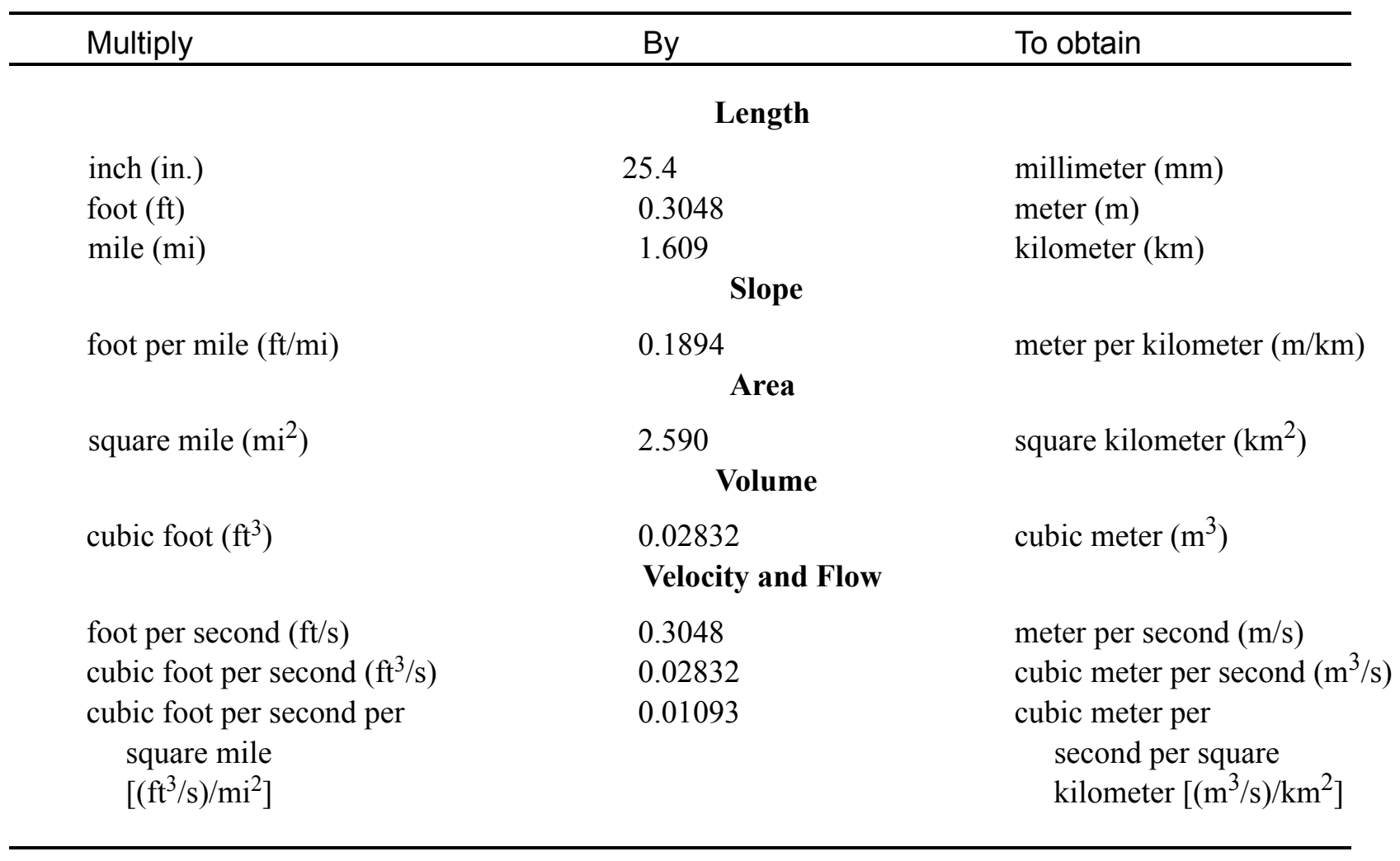

\section{OTHER ABBREVIATIONS}

$\begin{array}{lrlr}\mathrm{BF} & \text { bank full } & \text { LWW } & \text { left wingwall } \\ \mathrm{cfs} & \text { cubic feet per second } & \text { MC } & \text { main channel } \\ \mathrm{D}_{50} & \text { median diameter of bed material } & \text { RAB } & \text { right abutment } \\ \mathrm{DS} & \text { downstream } & \text { RABUT } & \text { face of right abutment } \\ \mathrm{elev} & \text { elevation } & \text { RB } & \text { right bank } \\ \mathrm{f} / \mathrm{p} & \text { flood plain } & \text { ROB } & \text { right overbank } \\ \mathrm{ft}^{2} & \text { square feet } & \text { RWW } & \text { right wingwall } \\ \mathrm{ft} / \mathrm{ft} & \text { feet per foot } & \text { TH } & \text { town highway } \\ \mathrm{JCT} & \text { junction } & \text { UB } & \text { under bridge } \\ \mathrm{LAB} & \text { left abutment } & \text { US } & \text { upstream } \\ \mathrm{LABUT} & \text { face of left abutment } & \text { USGS } & \text { United States Geological Survey } \\ \mathrm{LB} & \text { left bank } & \text { VTAOT Vermont Agency of Transportation } \\ \mathrm{LOB} & \text { left overbank } & \text { WSPRO } & \text { water-surface profile model }\end{array}$

In this report, the words "right" and "left" refer to directions that would be reported by an observer facing downstream. Sea level: In this report, "sea level" refers to the National Geodetic Vertical Datum of 1929-- a geodetic datum derived from a general adjustment of the first-order level nets of the United States and Canada, formerly called Sea Level Datum of 1929.

In the appendices, the above abbreviations may be combined. For example, USLB would represent upstream left bank. 


\title{
LEVEL II SCOUR ANALYSIS FOR BRIDGE 26 (JAMATH00010026) ON TOWN HIGHWAY 1, CROSSING BALL MOUNTAIN BROOK, JAMAICA, VERMONT
}

\author{
By Ronda L. Burns and Laura Medalie
}

\section{INTRODUCTION AND SUMMARY OF RESULTS}

This report provides the results of a detailed Level II analysis of scour potential at structure JAMATH00010026 on Town Highway 1 crossing Ball Mountain Brook, Jamaica, Vermont (figures 1-8). A Level II study is a basic engineering analysis of the site, including a quantitative analysis of stream stability and scour (U.S. Department of Transportation, 1993). Results of a Level I scour investigation also are included in Appendix E of this report. A Level I investigation provides a qualitative geomorphic characterization of the study site. Information on the bridge, gleaned from Vermont Agency of Transportation (VTAOT) files, was compiled prior to conducting Level I and Level II analyses and is found in Appendix D.

The site is in the Green Mountain section of the New England physiographic province in southern Vermont. The 29.3- $\mathrm{mi}^{2}$ drainage area is in a predominantly rural and forested basin. In the vicinity of the study site, the surface cover is forest.

In the study area, Ball Mountain Brook has an incised, sinuous channel with a slope of approximately $0.02 \mathrm{ft} / \mathrm{ft}$, an average channel top width of $74 \mathrm{ft}$ and an average bank height of $6 \mathrm{ft}$. The channel bed material ranges from gravel to boulder with a median grain size $\left(\mathrm{D}_{50}\right)$ of $82.6 \mathrm{~mm}(0.271 \mathrm{ft})$. The geomorphic assessment at the time of the Level I and Level II site visit on August 12, 1996, indicated that the reach was stable.

The Town Highway 1 crossing of Ball Mountain Brook is a 80-ft-long, two-lane bridge consisting of one 78-foot steel-beam span (Vermont Agency of Transportation, written communication, March 29, 1995). The opening length of the structure parallel to the bridge face is $75.7 \mathrm{ft}$. The bridge is supported by vertical, concrete abutments with wingwalls. A scour hole $2 \mathrm{ft}$ deeper than the mean thalweg depth was observed along the right abutment during the Level I assessment. The scour protection measures at the site were type- 4 stone fill (less than 60 inches diameter) along the left bank upstream and extending underneath the bridge and along the bank downstream and also along the right bank upstream tapering to type- 3 stone fill (less than 48 inches diameter) at the upstream end of the upstream right wingwall. Additional details describing conditions at the site are included in the Level II Summary and Appendices D and E. 
Scour depths and recommended rock rip-rap sizes were computed using the general guidelines described in Hydraulic Engineering Circular 18 (Richardson and others, 1995). Total scour at a highway crossing is comprised of three components: 1) long-term streambed degradation; 2) contraction scour (due to accelerated flow caused by a reduction in flow area at a bridge) and; 3 ) local scour (caused by accelerated flow around piers and abutments). Total scour is the sum of the three components. Equations are available to compute depths for contraction and local scour and a summary of the results of these computations follows.

Contraction scour for the modelled flows ranged from 1.0 to $2.7 \mathrm{ft}$. The worst-case contraction scour occurred at the incipient-overtopping discharge. Abutment scour ranged from 8.4 to $17.6 \mathrm{ft}$. The worst-case abutment scour for the right abutment occurred at the incipient-overtopping discharge. For the left abutment, the worst-case abutment scour occurred at the 500-year discharge. Additional information on scour depths and depths to armoring are included in the section titled "Scour Results". Scoured-streambed elevations, based on the calculated scour depths, are presented in tables 1 and 2. A cross-section of the scour computed at the bridge is presented in figure 8. Scour depths were calculated assuming an infinite depth of erosive material and a homogeneous particle-size distribution.

It is generally accepted that the Froehlich equation (abutment scour) gives "excessively conservative estimates of scour depths" (Richardson and others, 1995, p. 47). Usually, computed scour depths are evaluated in combination with other information including (but not limited to) historical performance during flood events, the geomorphic stability assessment, existing scour protection measures, and the results of the hydraulic analyses. Therefore, scour depths adopted by VTAOT may differ from the computed values documented herein. 


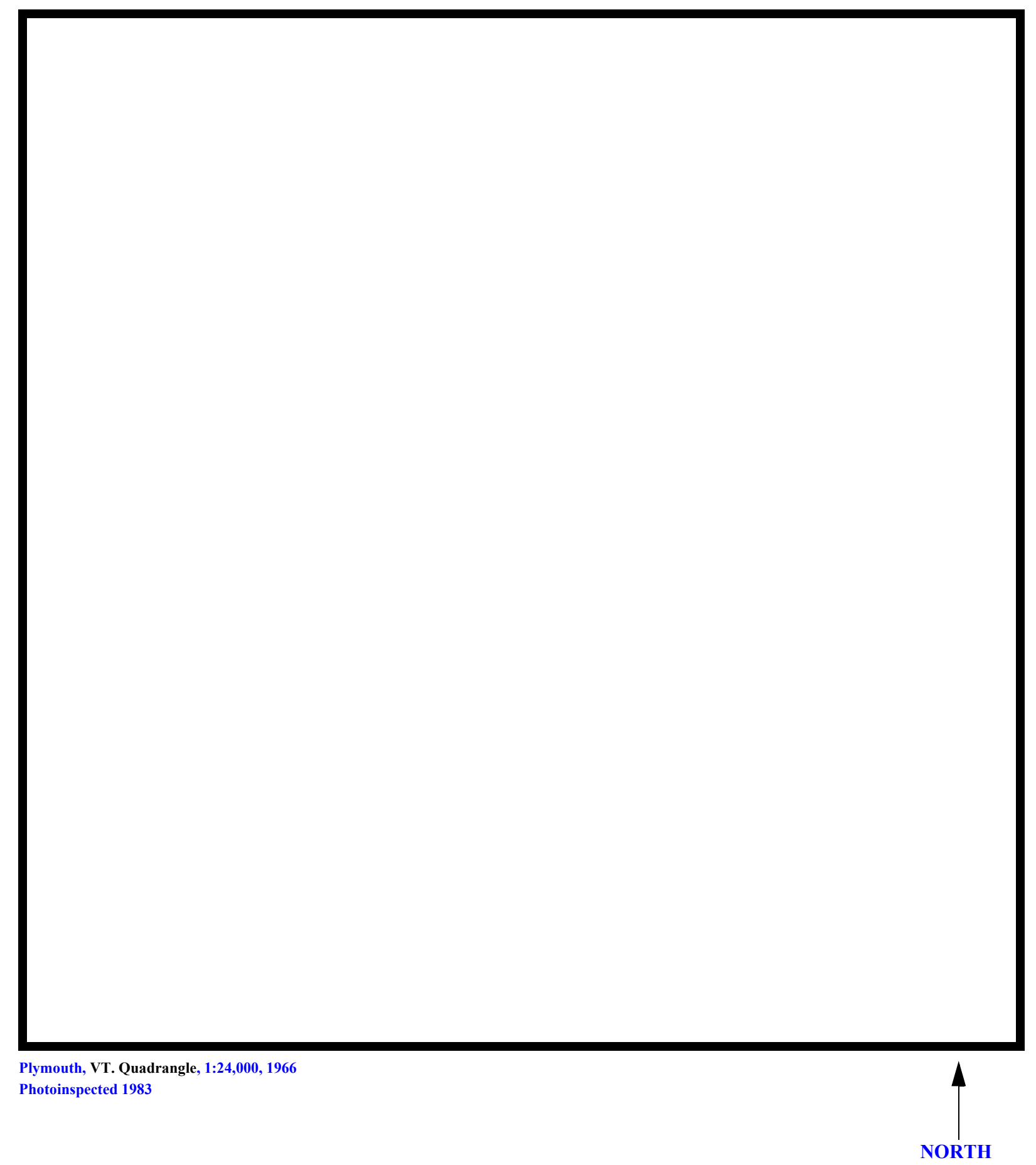

Figure 1. Location of study area on USGS 1:24,000 scale map. 
Figure 2. Location of study area on Vermont Agency of Transportation town highway map. 

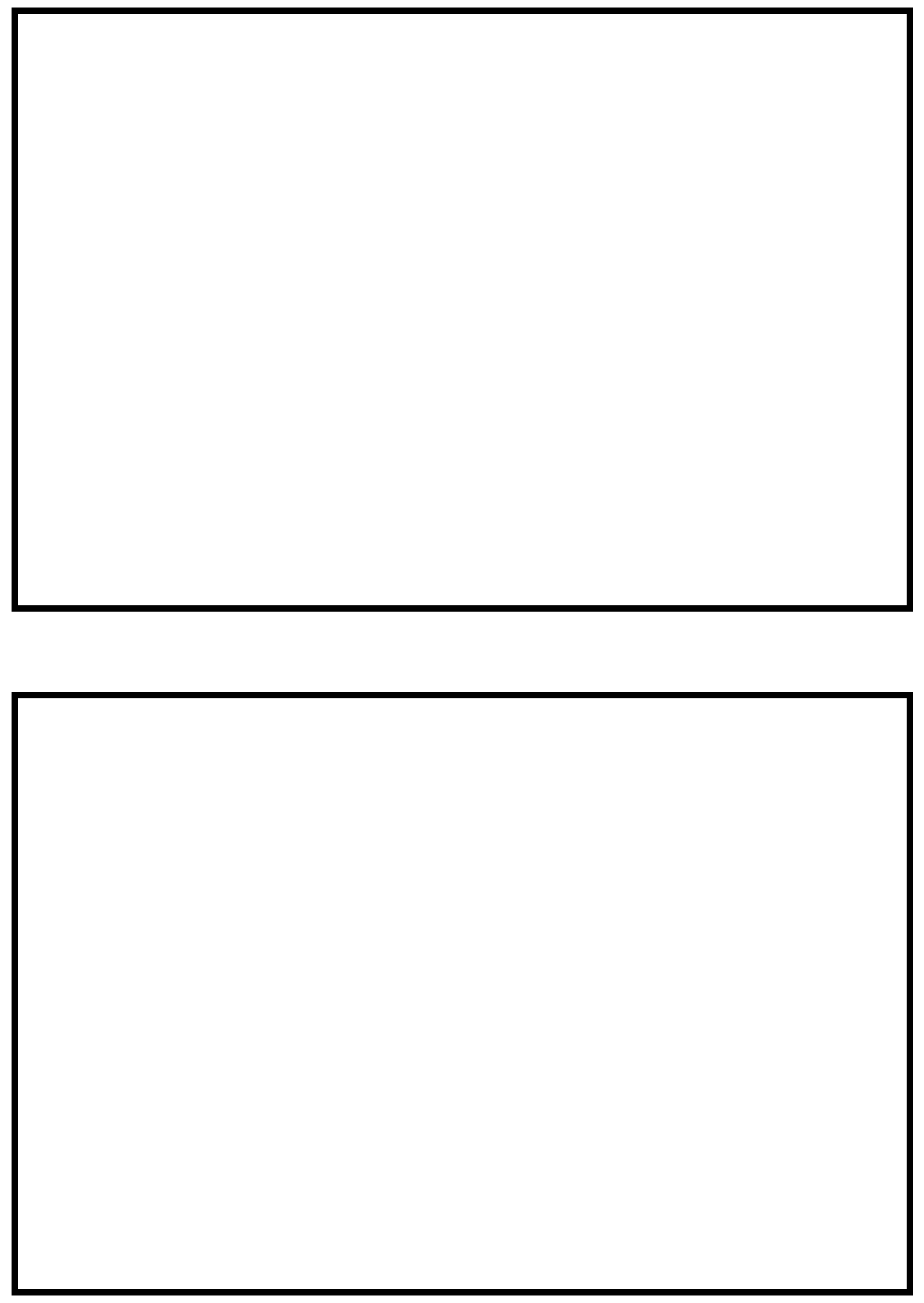

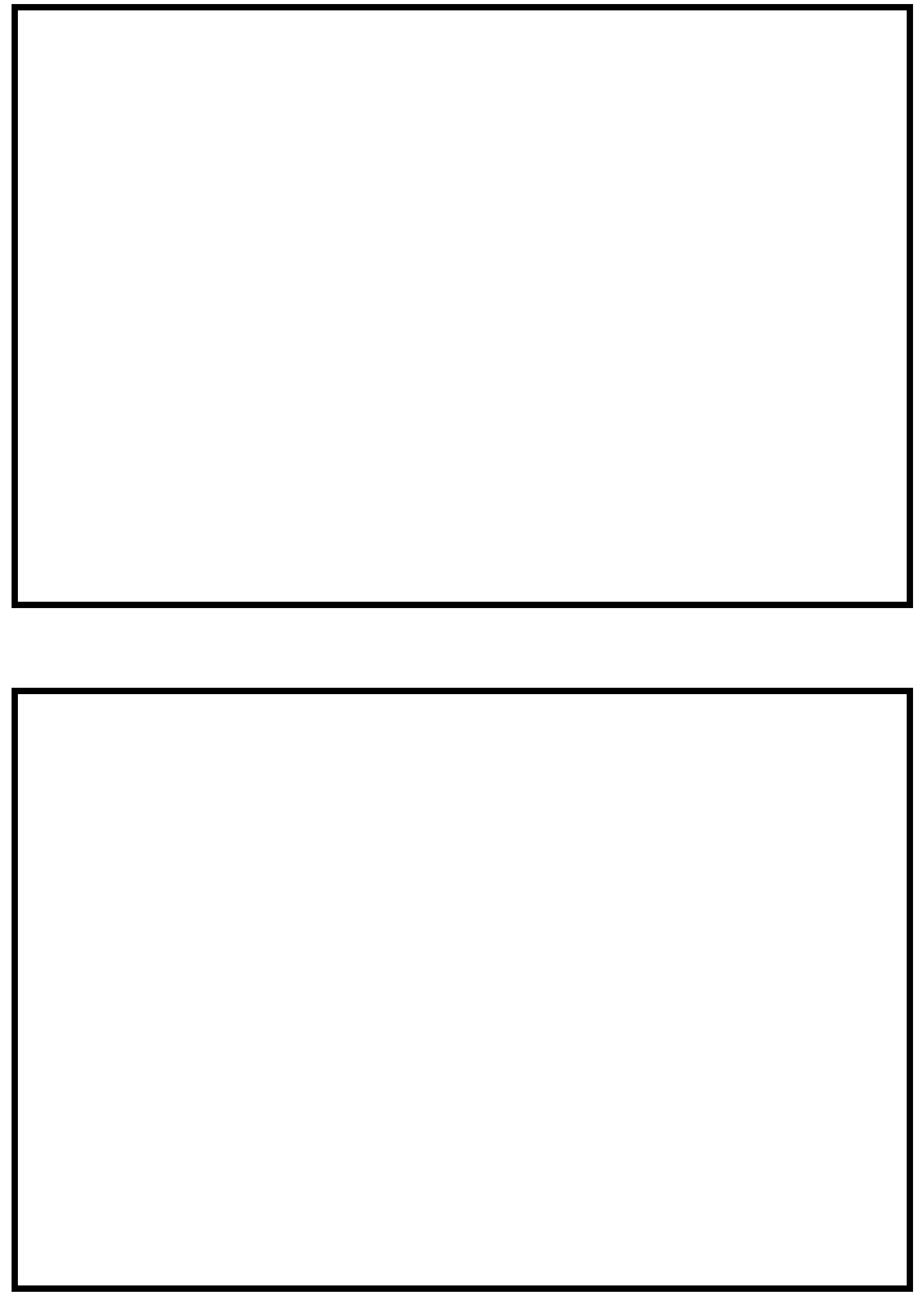


\section{LEVEL II SUMMARY}

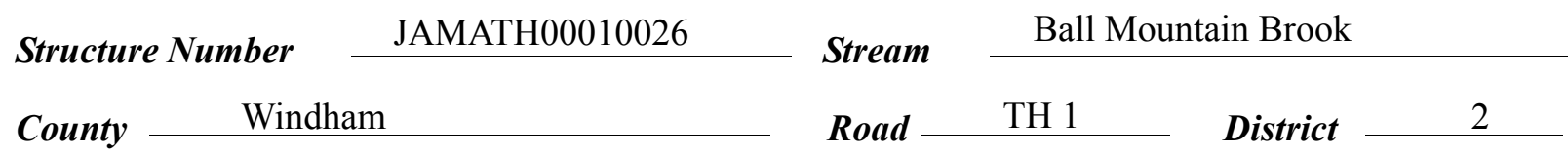

\section{Description of Bridge}

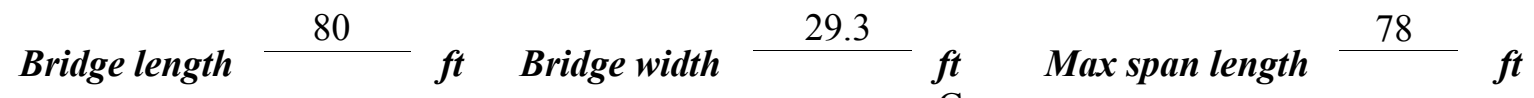
Alignment of bridge to road (on curve or straight)

\section{Abutment type} Vertical, concrete

Stone fill on abutment?

$$
\text { Yes }
$$

\section{Embankment type} Curve

\section{Sloping}

$$
08 / 12 / 96
$$

namanimtinn af atm n fill Type-4, around the upstream left wingwall, left abutment and downstream left wingwall. The stone fill is sloped to create a spill through abutment. Also, along the right upstream bank tappering to type-3 at the upstream right wingwall.

Abutments and wingwalls are concrete. There is a one foot deep scour hole along the right abutment.

Is bridge skewed to flood flow according to $\mathrm{No}^{\mathrm{N}}$ survey? $\quad \frac{\mathrm{Yes}}{\text { Angle }}$

\begin{tabular}{|c|c|c|c|}
\hline & $\begin{array}{c}\text { Date of incnortion } \\
08 / 12 / 96 \\
\end{array}$ & $\begin{array}{l}\text { Percent of almmust } \\
\text { blocked inortzontatly }\end{array}$ & $\begin{array}{l}\text { Percent of } 0 \\
\text { blocked verticatty }\end{array}$ \\
\hline & $08 / 12 / 96$ & 0 & 0 \\
\hline & Moderate. & & \\
\hline
\end{tabular}

Debris accumulation on bridge at time of Level I or Level II site visit:

\section{Potential for debris}

None 08/12/96.

Doscriho anv, fonturos noar ar at tho hridoo that mav, affort flow, (includo ahsorvation dato). 


\section{Description of the Geomorphic Setting}

General topography The channel is located within a moderate relief valley with steep valley walls on both sides.

Geomorphic conditions at bridge site: downstream (DS), upstream (US)

Date of inspection $\quad 08 / 12 / 96$

DS left: $\quad$ Steep valley wall.

DS right: $\quad$ Steep valley wall.

US left: $\quad$ Steep valley wall.

US right: $\quad$ Steep valley wall.

\section{Description of the Channel}

\begin{tabular}{llll} 
Average top width & Average depth & 6 & Cobbles/Boulders \\
\cline { 2 - 3 } & Cobbles/Boulders
\end{tabular}

Predominant bed material Bank material Sinuous but stable

with semi-alluvial channel boundaries.

Vegetative co 1 Trees.

DS left: $\quad$ Trees.

DS right: Trees

US left: $\quad$ Trees.

US right: $\quad$ Yes

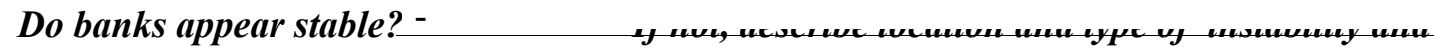
date of observation.

None $08 / 12 / 97$.

Describe any obstructions in channel and date of observation. 


\title{
Hydrology
}

Drainage area $\stackrel{29.3}{\mathbf{m}} \boldsymbol{m i}^{2}$

Percentage of drainage area in physiographic provinces: (approximate)

Physiographic province/section

New England/Green Mountain
Percent of drainage area 100

\begin{abstract}
Is drainage area considered rural or urban? Rural Describe any significant urbanization: None.
\end{abstract}

Is there a

Is there a USGS gage on the stream of interest? USGS gage description

USGS gage number

Gage drainage area $\mathrm{mi}^{2}$

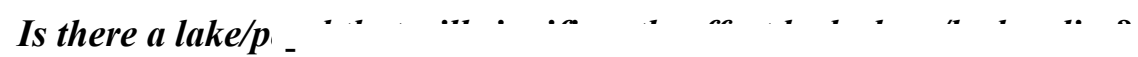

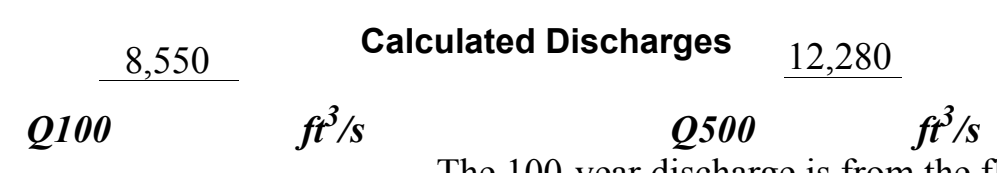

The 100-year discharge is from the flood frequency

estimates ayailable from the VTAOT database. The 500-year event was extrapolated from these estimates. The values used were within a range defined by flood frequency curves developed from several empirical methods (Benson, 1962; Johnson and Tasker, 1974; FHWA, 1983; Potter, 1957a\&b; Talbot, 1887). 


\section{Description of the Water-Surface Profile Model (WSPRO) Analysis}

Datum for WSPRO analysis (USGS survey, sea level, VTAOT plans)

USGS survey

Datum tie between USGS survey and VTAOT plans

Subtract 16.7 from the USGS

arbitrary survey datum to obtain the VT AOT plans' datum.

Description of reference marks used to determine USGS datum. $\quad$ RM1 is a brass survey

disk on top of the downstream end of the right abutment (elev. $517.35 \mathrm{ft}$, arbitrary survey

datum). RM2 is a nail in a telephone pole on the downstream right bank (elev. $514.61 \mathrm{ft}$,

arbitrary survey datum).

\section{Cross-Sections Used in WSPRO Analysis}

\begin{tabular}{|c|c|c|c|}
\hline${ }^{1}$ Cross-section & $\begin{array}{c}\text { Section } \\
\text { Reference } \\
\text { Distance } \\
\text { (SRD) in feet }\end{array}$ & $\begin{array}{c}{ }^{2} \text { Cross-section } \\
\text { development }\end{array}$ & Comments \\
\hline EXITX & -76 & 1 & Exit section \\
\hline FULLV & 0 & 2 & $\begin{array}{l}\text { Downstream Full-valley } \\
\text { section (Templated from } \\
\text { EXITX) }\end{array}$ \\
\hline BRIDG & 0 & 1 & Bridge section \\
\hline RDWAY & 16 & 1 & Road Grade section \\
\hline APPRO & 109 & 1 & Approach section \\
\hline
\end{tabular}

${ }^{1}$ For location of cross-sections see plan-view sketch included with Level I field form, Appendix E. For more detail on how cross-sections were developed see WSPRO input file. 


\section{Data and Assumptions Used in WSPRO Model}

Hydraulic analyses of the reach were done by use of the Federal Highway Administration's WSPRO step-backwater computer program (Shearman and others, 1986, and Shearman, 1990). The analyses reported herein reflect conditions existing at the site at the time of the study. Furthermore, in the development of the model it was necessary to assume no accumulation of debris or ice at the site. Results of the hydraulic model are presented in the Bridge Hydraulic Summary, Appendix B, and figure 7.

Channel roughness factors (Manning's " $n$ ") used in the hydraulic model were estimated using field inspections at each cross section following the general guidelines described by Arcement and Schneider (1989). Final adjustments to the values were made during the modelling of the reach. Channel " $n$ " values for the reach ranged from 0.060 to 0.065 , and overbank " $n$ " values ranged from 0.035 to 0.075 .

Normal depth at the exit section (EXITX) was assumed as the starting water surface for the 100-year and incipient over-topping discharges. This depth was computed by use of the slope-conveyance method outlined in the user's manual for WSPRO (Shearman, 1990). The slope used was $0.022 \mathrm{ft} / \mathrm{ft}$ which was estimated from the 100 -year water-surface profile slope downstream of the bridge in the Flood Insurance Study for Jamaica, VT (Federal Emergency Management Agency, 1988). Critical depth was used for the starting water surfaces at the exit section (EXITX) for the 500-year discharge. Normal depth was computed as approximately 0.3 $\mathrm{ft}$ below critical depth by use of the slope-conveyance method.

The approach section (APPRO) was surveyed one bridge length upstream of the upstream face as recommended by Shearman and others (1986). This location also provides a consistent method for determining scour variables.

For the incipient-overtopping discharge, WSPRO assumes critical depth at the bridge section. A supercritical model was developed for this discharge. By analyzing both the supercritical and subcritical profiles, it was determined that the water surface profile does pass through critical depth within the bridge opening. Thus, the assumption of critical depth at the bridge is a satisfactory solution. 


\section{Bridge Hydraulics Summary}

$\begin{array}{lll}\text { Average bridge embankment elevation } & 519.0 \\ \text { Average low steel elevation } & 515.0 & \boldsymbol{f t}\end{array}$

100-year discharge $\quad 8,550 \quad \mathrm{ft}^{3} / \mathrm{s}$

Water-surface elevation in bridge opening $\quad 509.6 \mathrm{ft}$

Road overtopping? ___ No Discharge over road ___ - $\mathrm{ft}^{3} / \mathrm{s}$

Area of flow in bridge opening $\quad 557 \quad \mathrm{ft}^{2}$

Average velocity in bridge opening $15.4 \mathrm{ft} / \mathrm{s}$

$\begin{array}{llll}\text { Maximum WSPRO tube velocity at bridge } & 19.4 \mathrm{ft} / \mathrm{s}\end{array}$

Water-surface elevation at Approach section with bridge 513.8

Water-surface elevation at Approach section without bridge $\quad 511.8$

Amount of backwater caused by bridge $\quad 2.0 \quad$ it

500-year discharge $\quad 12,280 \quad \mathrm{ft}^{3} / \mathrm{s}$

Water-surface elevation in bridge opening $\quad 515.0 \mathrm{ft}$

Road overtopping? ____ Yes Discharge over road _ $1,679 \mathrm{ft}^{3} / \mathrm{s}$

Area of flow in bridge opening $\quad 926 \quad \mathrm{ft}^{2}$

Average velocity in bridge opening $11.5 \mathrm{ft} / \mathrm{s}$

Maximum WSPRO tube velocity at bridge 15.5 , s

Water-surface elevation at Approach section with bridge

Water-surface elevation at Approach section without bridge

518.3

Amount of backwater caused by bridge 4.3 .t

Incipient overtopping discharge $\quad 9,250 \quad \mathrm{ft}^{3} / \mathrm{s}$

Water-surface elevation in bridge opening $\quad 509.9 \quad$ t

Area of flow in bridge opening $\quad 574 \quad \mathrm{ft}^{2}$

Average velocity in bridge opening $\quad 16.1 \quad \mathrm{ft} / \mathrm{s}$

Maximum WSPRO tube velocity at bridge $\quad 20.4 \quad \mathrm{ft} / \mathrm{s}$

Water-surface elevation at Approach section with bridge

Water-surface elevation at Approach section without bridge

514.6

Amount of backwater caused by bridge $\quad 2.4$, t 


\section{Scour Analysis Summary}

\section{Special Conditions or Assumptions Made in Scour Analysis}

Scour depths were computed using the general guidelines described in Hydraulic Engineering Circular 18 (Richardson and others, 1995). Scour depths were calculated assuming an infinite depth of erosive material and a homogeneous particle-size distribution. The results of the scour analysis are presented in tables 1 and 2 and a graph of the scour depths is presented in figure 8 .

Contraction scour for the 100-year and incipient over-topping discharges was computed by use of the live-bed contraction scour equation (Richardson and others, 1995, p. 30, equation 17). At this site, the 500-year discharge resulted in unsubmerged orifice flow. Contraction scour at bridges with orifice flow is best estimated by use of the Chang pressure-flow scour equation (oral communication, J. Sterling Jones, October 4, 1996). Thus, contraction scour for the 500 -year event was computed by use of the Chang equation (Richardson and others, 1995, p. 145-146). The streambed armoring depths computed suggest that armoring will not limit the depth of contraction scour.

For comparison, estimates of contraction scour at the 500-year discharge were also computed by use of the Laursen clear-water contraction scour equation and the Umbrell pressure-flow equation (Richardson and others, 1995, p. 144) and are presented in Appendix F. Furthermore, since the 500-year discharge was unsubmerged orifice flow, contraction scour was computed by substituting estimates for the depth of flow at the downstream bridge face in the contraction scour equations. Results with respect to these substitutions are provided in Appendix F.

Abutment scour was computed by use of the Froehlich equation (Richardson and others, 1995, p. 48, equation 28). Variables for the Froehlich equation include the Froude number of the flow approaching the embankments, the length of the embankment blocking flow, and the depth of flow approaching the embankment less any roadway overtopping.

Because the influence of scour processes on the spill-through embankment material is uncertain, the scour depth at the left vertical concrete abutment wall is unknown. Therefore, the total scour depth computed at the toe of the embankment was applied for the entire spill-through embankment as shown in figure 8 . 


\section{Scour Results}

100-yr discharge 500-yrdischarge

Incipient

overtopping

Contraction scour:

(Scour depths in feet)

Main channel

Live-bed scour

Clear-water scour

Depth to armoring

Left overbank

Right overbank

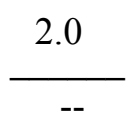

$34.9^{-}$

---
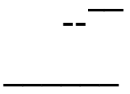

Left abutment

Right abutment

Pier scour

Pier 1

Pier 2

Pier 3

\section{Abutments:}

\section{Left abutment}

Right abutment

Piers:

Pier 1

Pier 2

\section{Riprap Sizing}

8.4

16.7-

11.2

8.9

$17.0-$

17.6-
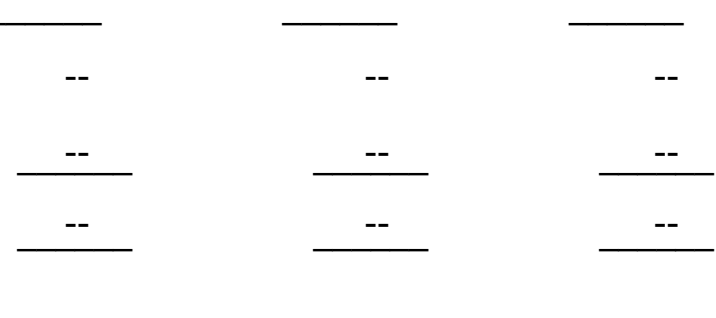

2.7

$--$

$47.8^{-}$

---

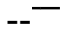

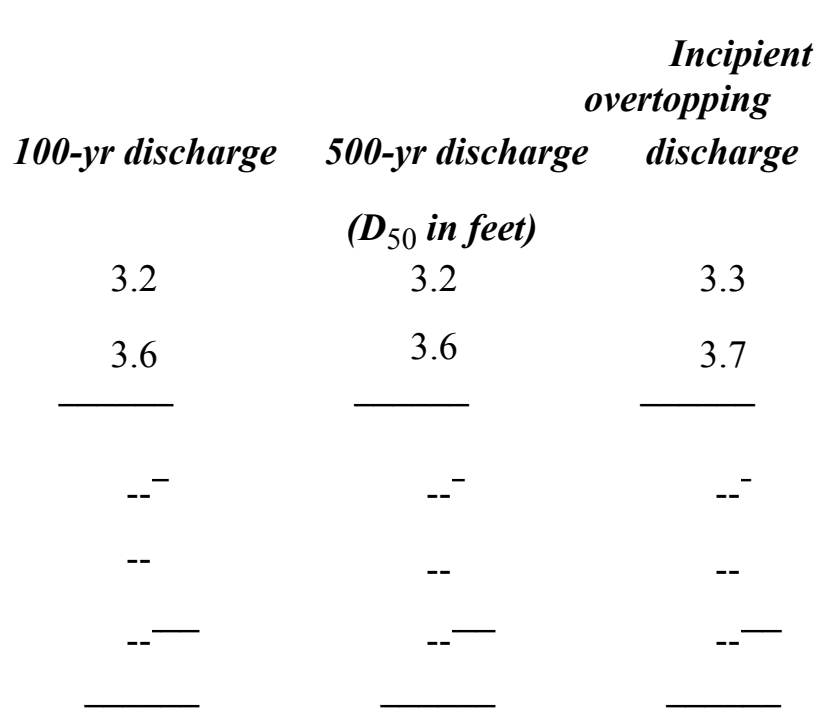




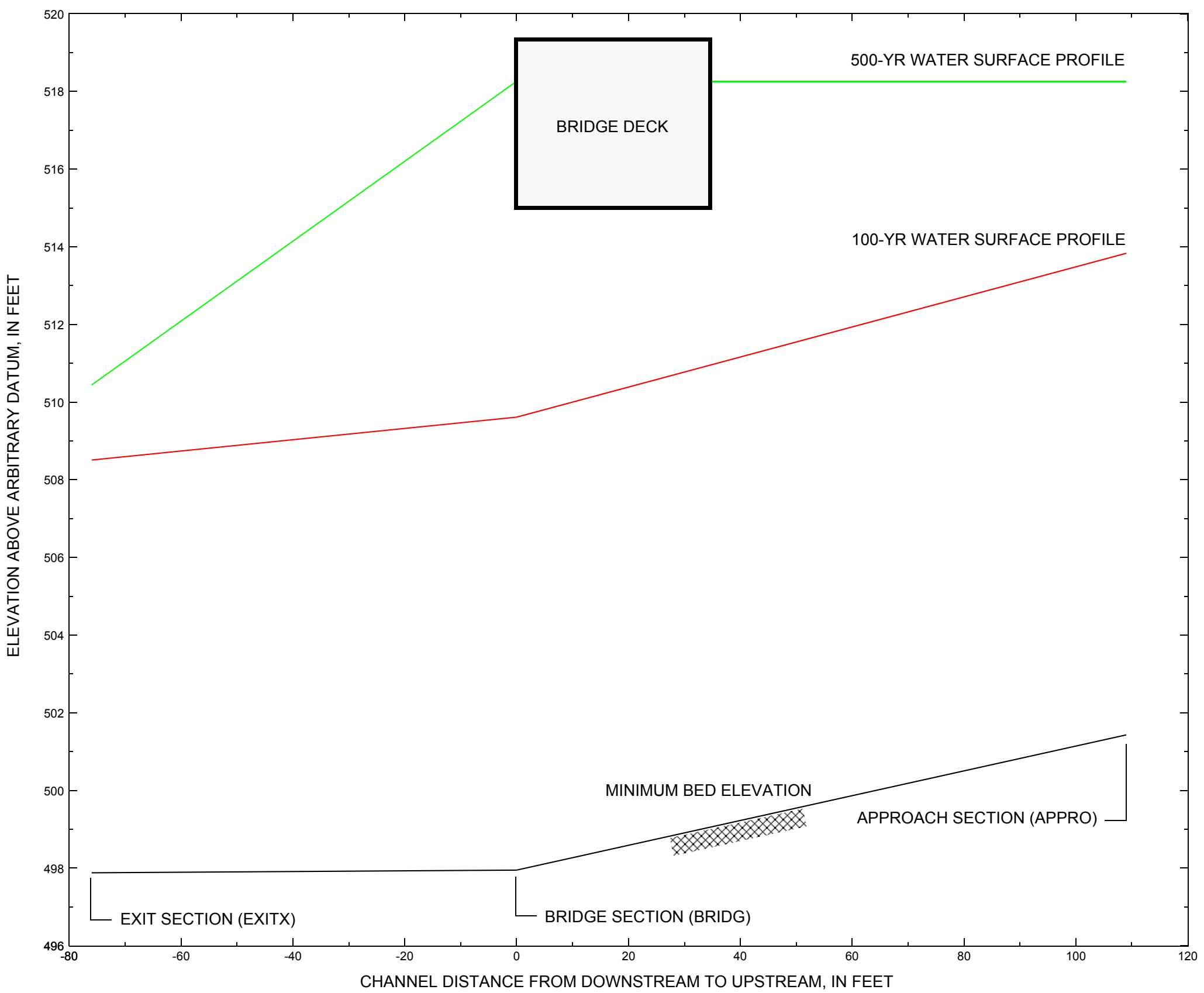

Figure 7. Water-surface profiles for the 100- and 500-yr discharges at structure JAMATH00010026 on Town Highway 1, crossing Ball Mountain Brook, Jamaica, Vermont. 


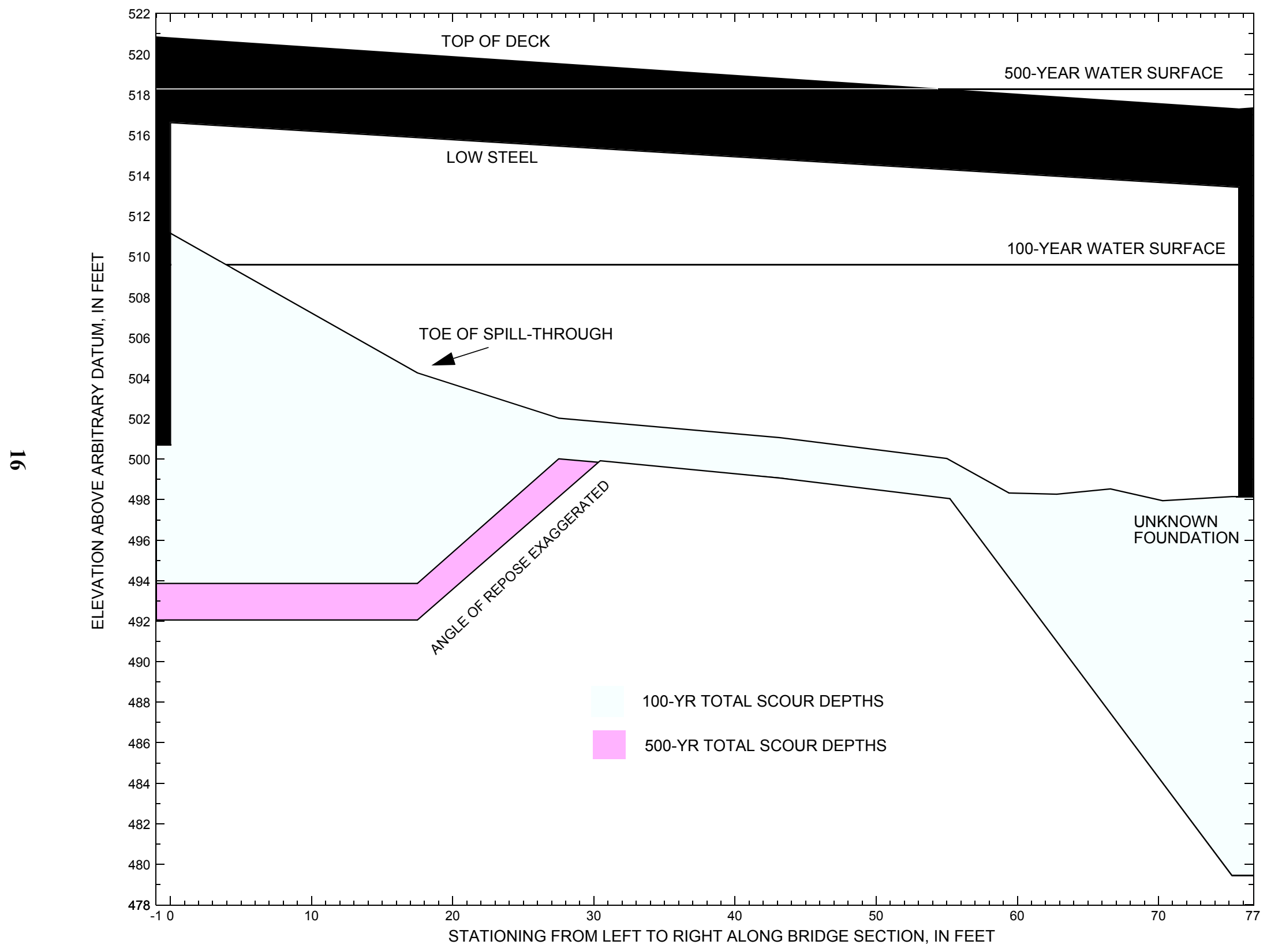

Figure 8. Scour elevations for the 100-yr and 500-yr discharges at structure JAMATH00010026 on Town Highway 1, crossing Ball Mountain Brook, Jamaica, Vermont. 
Table 1. Remaining footing/pile depth at abutments for the 100-year discharge at structure JAMATH00010026 on Town Highway 1, crossing Ball Mountain Brook, Jamaica, Vermont.

[VTAOT, Vermont Agency of Transportation; --, no data]

\begin{tabular}{|c|c|c|c|c|c|c|c|c|c|c|c|}
\hline Description & Station $^{1}$ & $\begin{array}{c}\text { VTAOT } \\
\text { bridge seat } \\
\text { elevation } \\
\text { (feet) }\end{array}$ & $\begin{array}{c}\text { Surveyed } \\
\text { minimum } \\
\text { low-chord } \\
\text { elevation } \\
\text { (feet) }\end{array}$ & $\begin{array}{c}\text { Bottom of } \\
\text { footing } \\
\text { elevation } \\
\text { (feet) }\end{array}$ & $\begin{array}{c}\text { Channel } \\
\text { elevation at } \\
\text { abutment/ } \\
\text { pier }^{2} \\
\text { (feet) }\end{array}$ & $\begin{array}{l}\text { Contraction } \\
\text { scour depth } \\
\text { (feet) }\end{array}$ & $\begin{array}{l}\text { Abutment } \\
\text { scour } \\
\text { depth } \\
\text { (feet) }\end{array}$ & $\begin{array}{l}\text { Pier } \\
\text { scour } \\
\text { depth } \\
\text { (feet) }\end{array}$ & $\begin{array}{l}\text { Depth of } \\
\text { total scour } \\
\text { (feet) }\end{array}$ & $\begin{array}{c}\text { Elevation of } \\
\text { scour }^{2} \\
\text { (feet) }\end{array}$ & $\begin{array}{c}\text { Remaining } \\
\text { footing/pile } \\
\text { depth } \\
\text { (feet) }\end{array}$ \\
\hline \multicolumn{12}{|c|}{100 -yr. discharge is 8,550 cubic-feet per second } \\
\hline Left abutment & 0.0 & 500.0 & 516.6 & 500.7 & 511.2 & -- & -- & -- & -- & -- & -6.8 \\
\hline LABUT toe & 17.5 & -- & -- & -- & 504.3 & 2.0 & 8.4 & -- & 10.4 & 493.9 & -- \\
\hline Right abutment & 75.7 & 496.6 & 513.4 & -- & 498.2 & 2.0 & 16.7 & -- & 18.7 & 479.5 & -- \\
\hline
\end{tabular}

1.Measured along the face of the most constricting side of the bridge.

2.Arbitrary datum for this study.

Table 2. Remaining footing/pile depth at abutments for the 500-year discharge at structure JAMATH00010026 on Town Highway 1, crossing Ball Mountain Brook, Jamaica, Vermont.

[VTAOT, Vermont Agency of Transportation; --, no data]

\begin{tabular}{|c|c|c|c|c|c|c|c|c|c|c|c|}
\hline Description & Station $^{1}$ & $\begin{array}{l}\text { VTAOT } \\
\text { bridge seat } \\
\text { elevation } \\
\text { (feet) }\end{array}$ & $\begin{array}{c}\text { Surveyed } \\
\text { minimum } \\
\text { low-chord } \\
\text { elevation } \\
\text { (feet) }\end{array}$ & $\begin{array}{c}\text { Bottom of } \\
\text { footing } \\
\text { elevation } \\
\text { (feet) }\end{array}$ & $\begin{array}{c}\text { Channel } \\
\text { elevation at } \\
\text { abutment/ } \\
\text { pier }^{2} \\
\text { (feet) }\end{array}$ & $\begin{array}{l}\text { Contraction } \\
\text { scour depth } \\
\text { (feet) }\end{array}$ & $\begin{array}{l}\text { Abutment } \\
\text { scour } \\
\text { depth } \\
\text { (feet) }\end{array}$ & $\begin{array}{l}\text { Pier } \\
\text { scour } \\
\text { depth } \\
\text { (feet) }\end{array}$ & $\begin{array}{l}\text { Depth of } \\
\text { total scour } \\
\text { (feet) }\end{array}$ & $\begin{array}{c}\text { Elevation of } \\
\text { scour }^{2} \\
\text { (feet) }\end{array}$ & $\begin{array}{c}\text { Remaining } \\
\text { footing/pile } \\
\text { depth } \\
\text { (feet) }\end{array}$ \\
\hline \multicolumn{12}{|c|}{500 -yr. discharge is 12,280 cubic-feet per second } \\
\hline Left abutment & 0.0 & 500.0 & 516.6 & 500.7 & 511.2 & -- & -- & -- & -- & -- & -8.6 \\
\hline LABUT toe & 17.5 & -- & -- & -- & 504.3 & 1.0 & 11.2 & -- & 12.2 & 492.1 & -- \\
\hline Right abutment & 75.7 & 496.6 & 513.4 & -- & 498.2 & 1.0 & 17.1 & -- & 18.1 & 480.1 & -- \\
\hline
\end{tabular}

1.Measured along the face of the most constricting side of the bridge.

2.Arbitrary datum for this study. 


\section{SELECTED REFERENCES}

Arcement, G.J., Jr., and Schneider, V.R., 1989, Guide for selecting Manning's roughness coefficients for natural channels and flood plains:

U.S. Geological Survey Water-Supply Paper 2339, 38 p.

Barnes, H.H., Jr., 1967, Roughness characteristics of natural channels: U.S. Geological Survey Water-Supply Paper 1849,213 p.

Benson, M. A., 1962, Factors Influencing the Occurrence of Floods in a Humid Region of Diverse Terrain: U.S. Geological Survey WaterSupply Paper 1580-B, 64 p.

Brown, S.A. and Clyde, E.S., 1989, Design of riprap revetment: Federal Highway Administration Hydraulic Engineering Circular No. 11, Publication FHWA-IP-89-016, 156 p.

Federal Highway Administration, 1983, Runoff estimates for small watersheds and development of sound design: Federal Highway Administration Report FHWA-RD-77-158.

Federal Highway Administration, 1993, Stream Stability and Scour at Highway Bridges: Participant Workbook: Federal Highway Administration Report FHWA-HI-91-011.

Federal Emergency Management Agency, 1988, Flood Insurance Study, Town of Jamaica, Windham County, Vermont: Washington, D.C., May 17, 1988.

Froehlich, D.C., 1989, Local scour at bridge abutments in Ports, M.A., ed., Hydraulic Engineering--Proceedings of the 1989 National Conference on Hydraulic Engineering: New York, American Society of Civil Engineers, p. 13-18.

Hayes, D.C.,1993, Site selection and collection of bridge-scour data in Delaware, Maryland, and Virginia: U.S. Geological Survey WaterResources Investigation Report 93-4017, 23 p.

Interagency Advisory Committee on Water Data, 1982, Guidelines for determining flood flow frequency: U.S. Geological Survey, Bulletin 17B of the Hydrology Subcommittee, 190 p.

Johnson, C.G. and Tasker, G.D.,1974, Progress report on flood magnitude and frequency of Vermont streams: U.S. Geological Survey OpenFile Report 74-130, 37 p.

Lagasse, P.F., Schall, J.D., Johnson, F., Richardson, E.V., Chang, F., 1995, Stream Stability at Highway Structures: Federal Highway Administration Hydraulic Engineering Circular No. 20, Publication FHWA-IP-90-014, 144 p.

Laursen, E.M., 1960, Scour at bridge crossings: Journal of the Hydraulics Division, American Society of Civil Engineers, v. 86, no. HY2, p. 39-53.

Potter, W. D., 1957a, Peak rates of runoff in the Adirondack, White Mountains, and Maine woods area, Bureau of Public Roads

Potter, W. D., 1957b, Peak rates of runoff in the New England Hill and Lowland area, Bureau of Public Roads

Richardson, E.V. and Davis, S.R., 1995, Evaluating scour at bridges: Federal Highway Administration Hydraulic Engineering Circular No. 18, Publication FHWA-IP-90-017, 204 p.

Richardson, E.V., Simons, D.B., and Julien, P.Y., 1990, Highways in the river environment: Federal Highway Administration Publication FHWA-HI-90-016.

Ritter, D.F., 1984, Process Geomorphology: W.C. Brown Co., Debuque, Iowa, 603 p.

Shearman, J.O., 1990, User's manual for WSPRO--a computer model for water surface profile computations: Federal Highway Administration Publication FHWA-IP-89-027, 187 p.

Shearman, J.O., Kirby, W.H., Schneider, V.R., and Flippo, H.N., 1986, Bridge waterways analysis model; research report: Federal Highway Administration Publication FHWA-RD-86-108, 112 p.

Talbot, A.N., 1887, The determination of water-way for bridges and culverts.

U.S. Department of Transportation, 1993, Stream stability and scour at highway bridges, Participant Workbook: Federal Highway Administration Publication FHWA HI-91-011.

U.S. Geological Survey, 1986, Jamaica, Vermont 7.5 Minute Series quadrangle map: U.S. Geological Survey Topographic Maps, Scale $1: 24,000$. 


\section{APPENDIX A: \\ WSPRO INPUT FILE}


WSPRO INPUT FILE

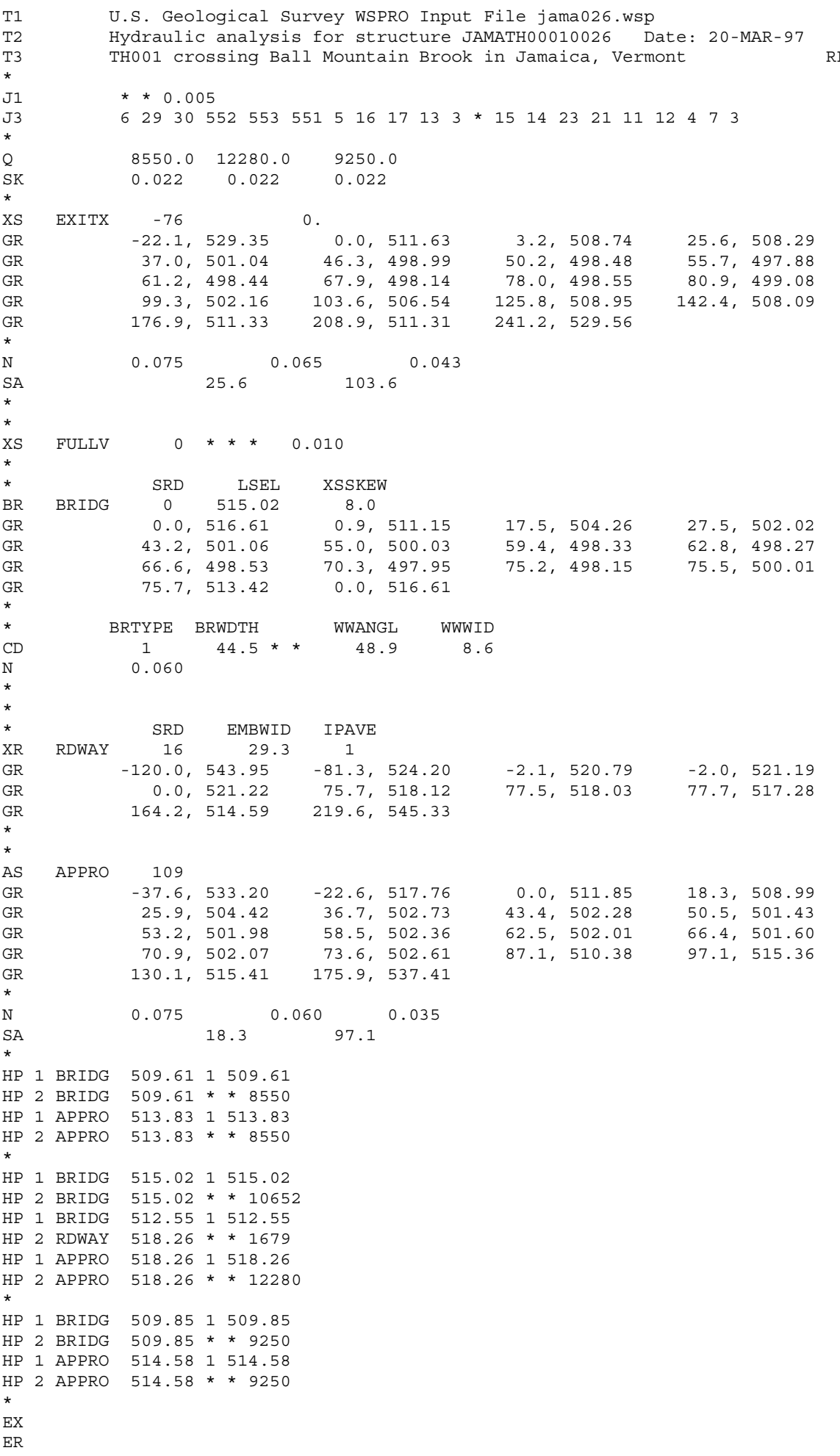




\section{APPENDIX B: \\ WSPRO OUTPUT FILE}


WSPRO OUTPUT FILE

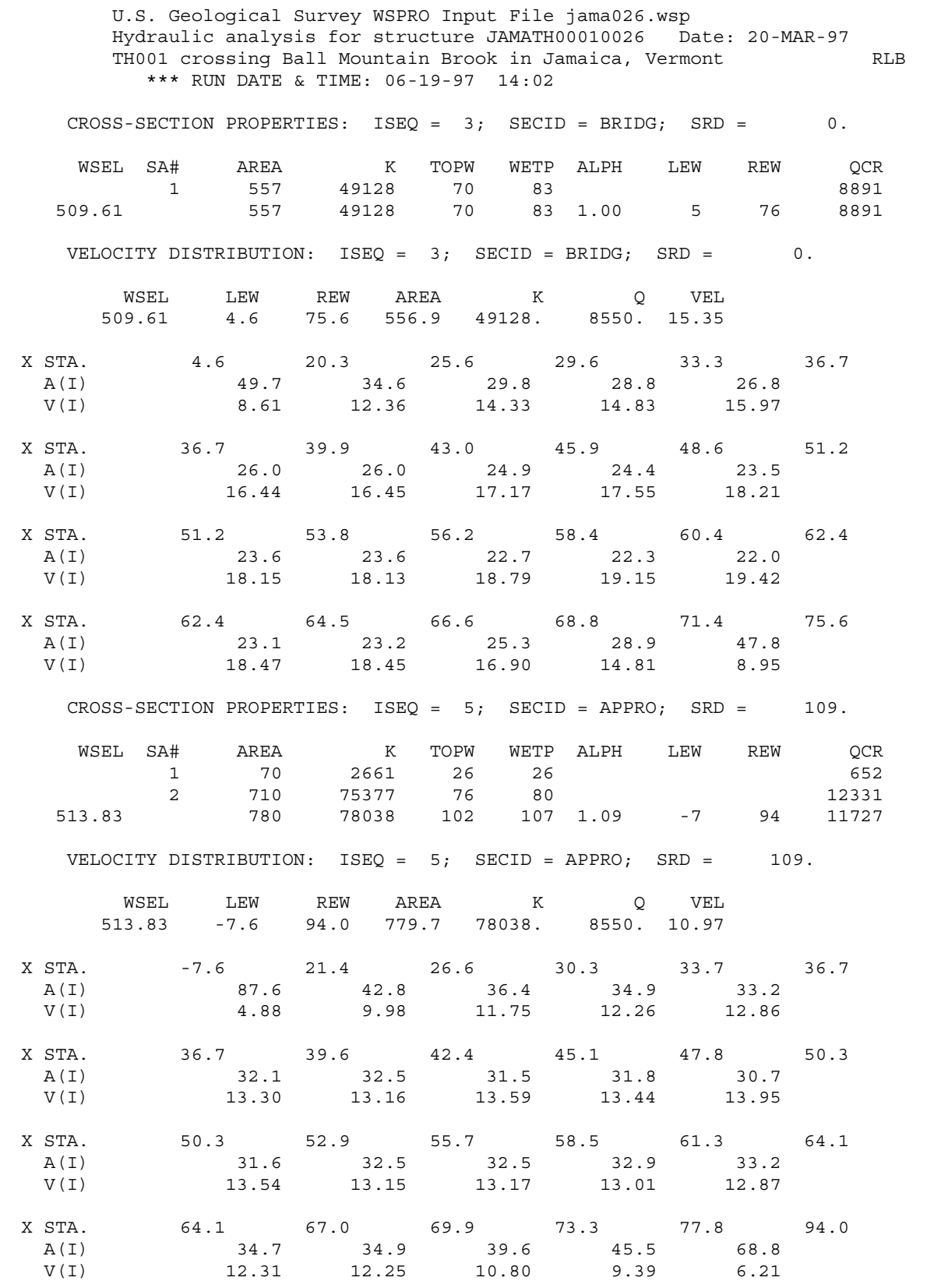


WSPRO OUTPUT FILE (continued)

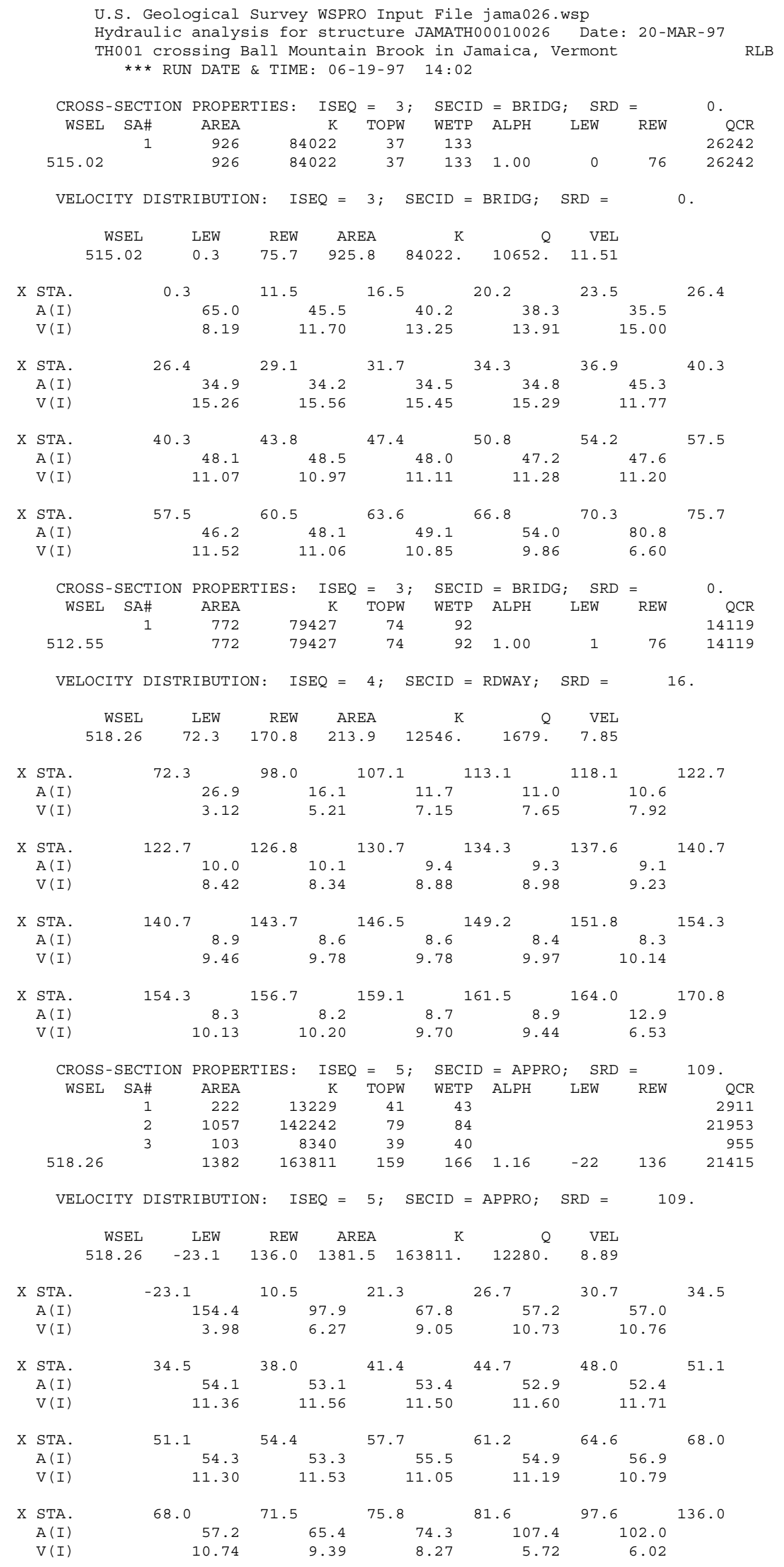


WSPRO OUTPUT FILE (continued)

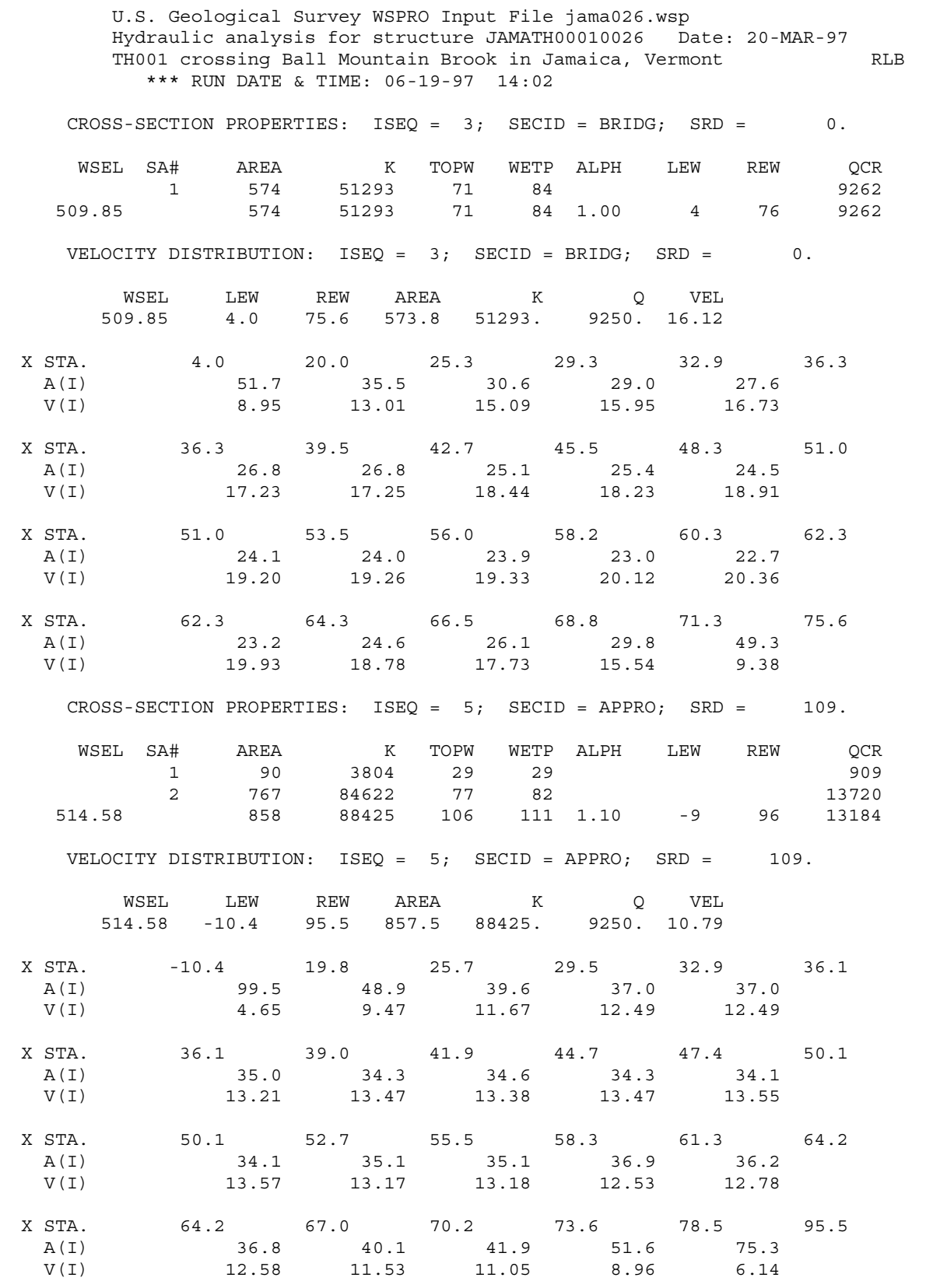


WSPRO OUTPUT FILE (continued)

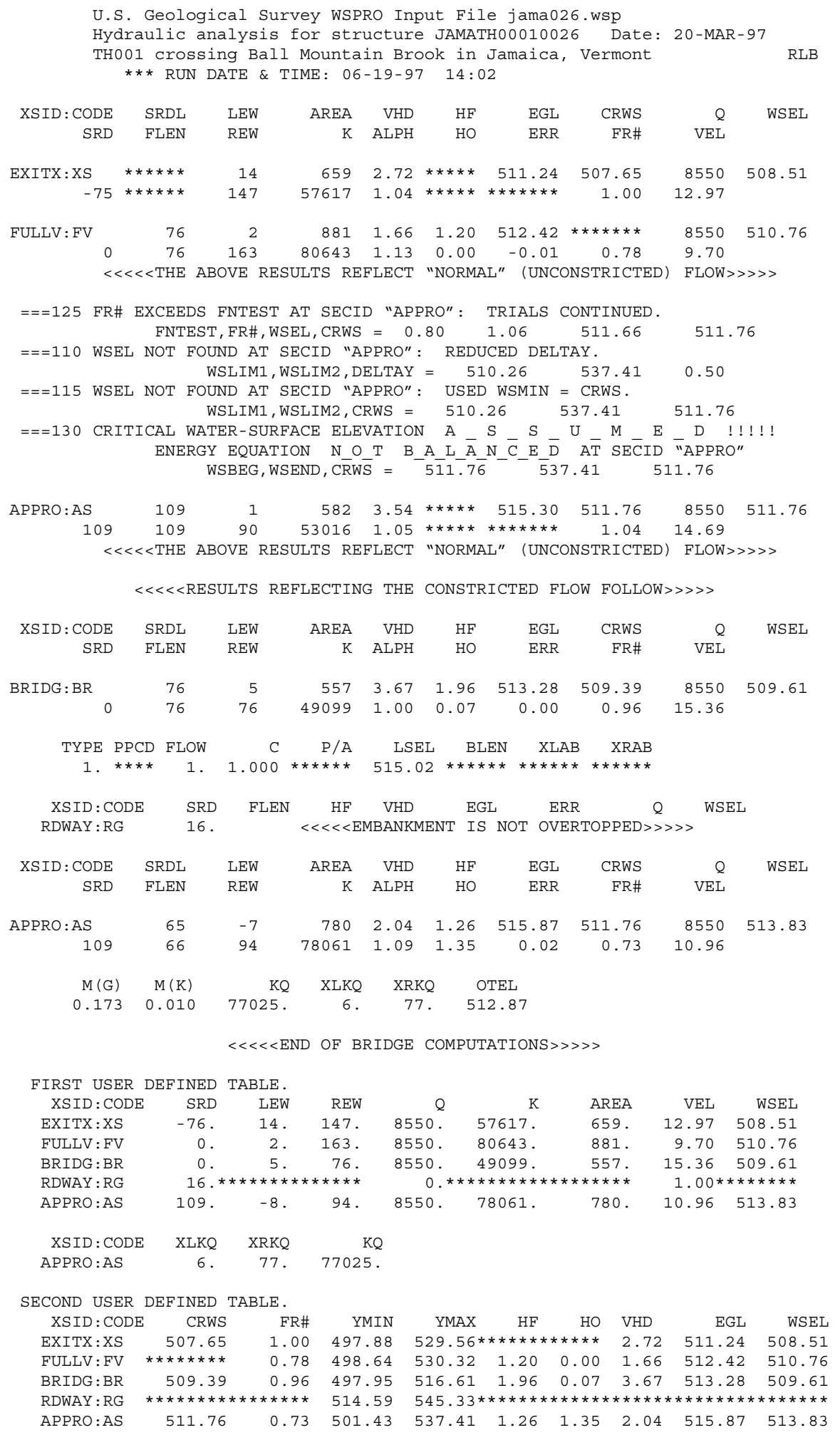


WSPRO OUTPUT FILE (continued)

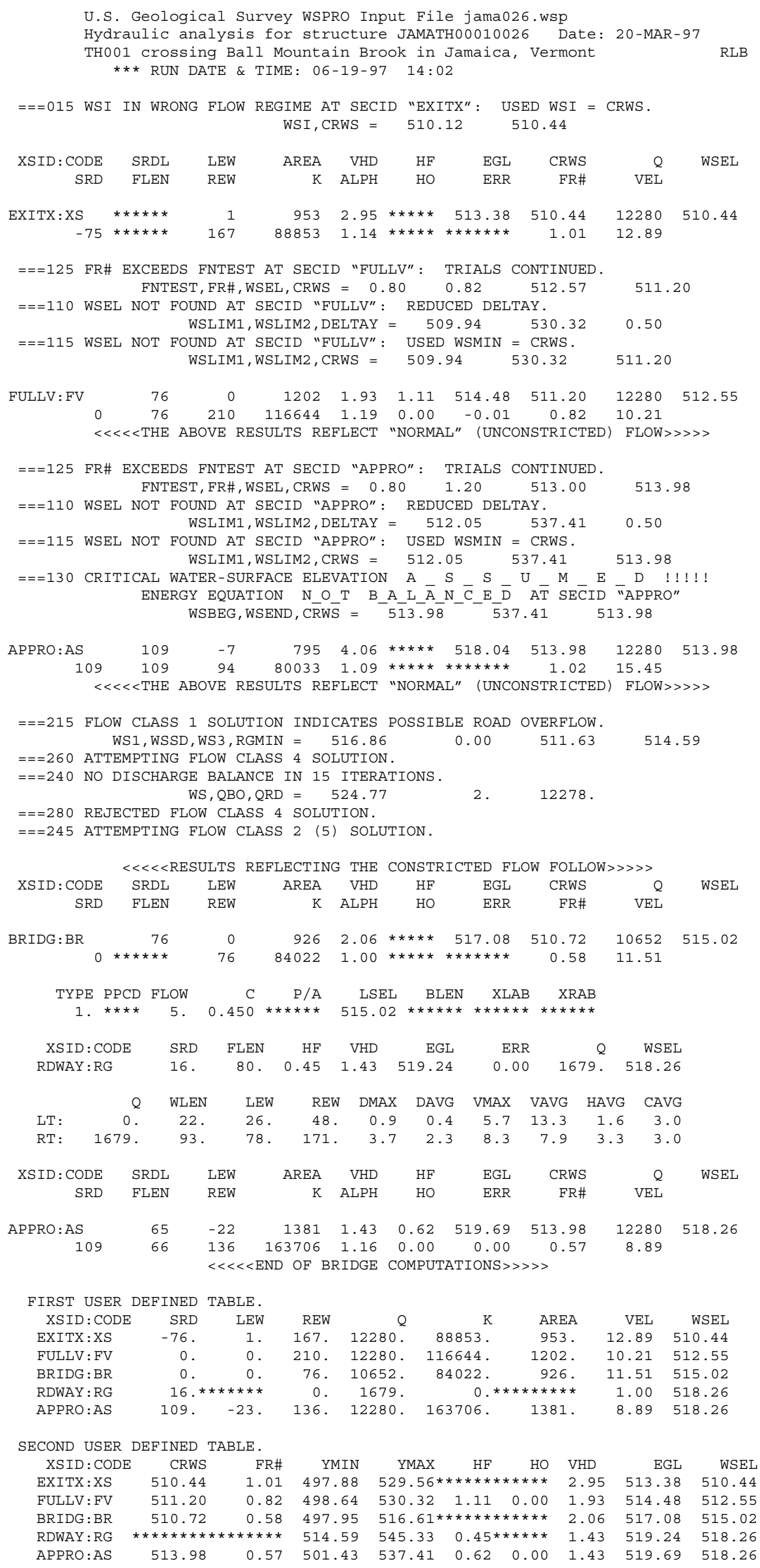


WSPRO OUTPUT FILE (continued)

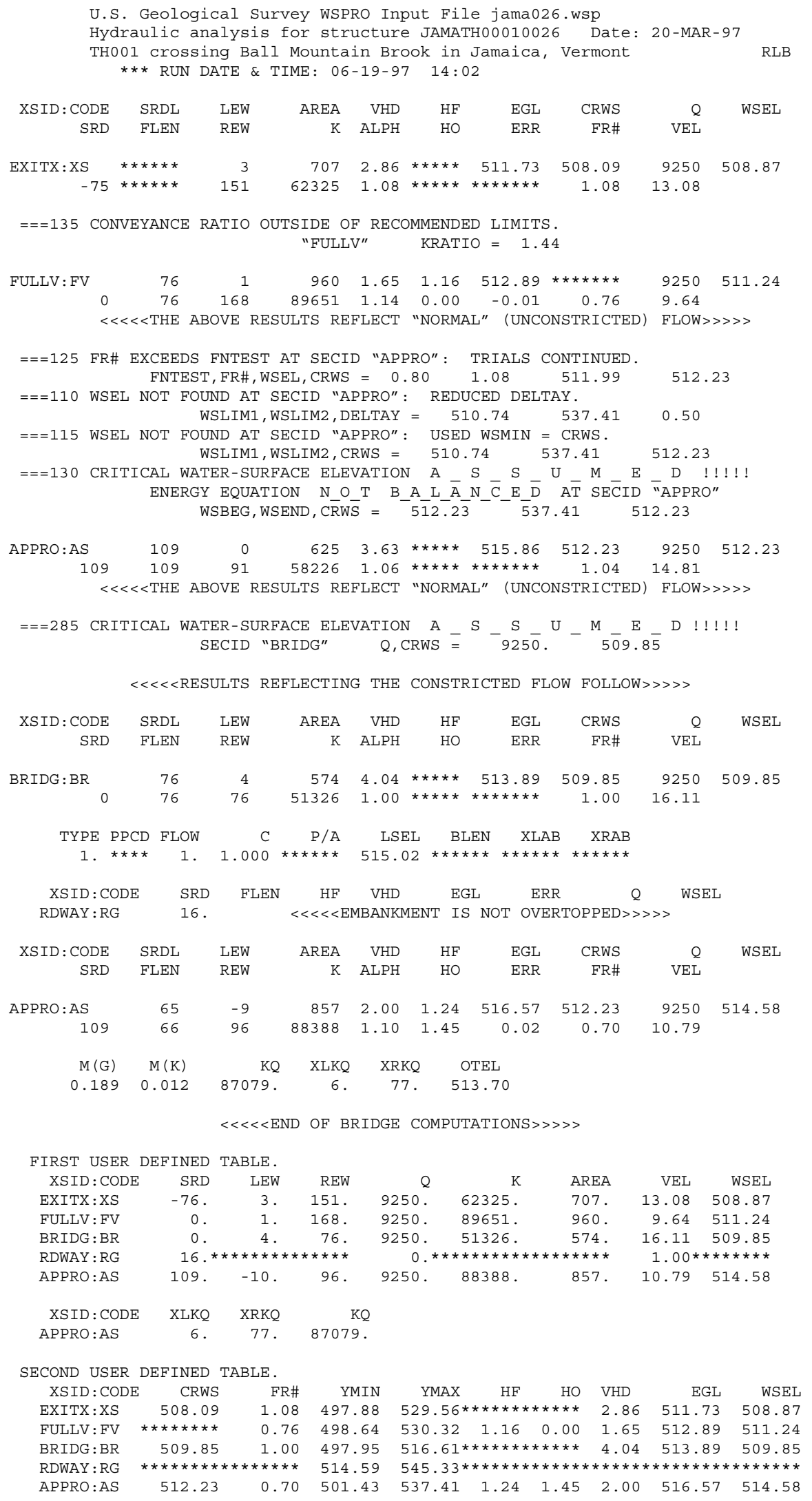




\section{APPENDIX C:}

\section{BED-MATERIAL PARTICLE-SIZE DISTRIBUTION}




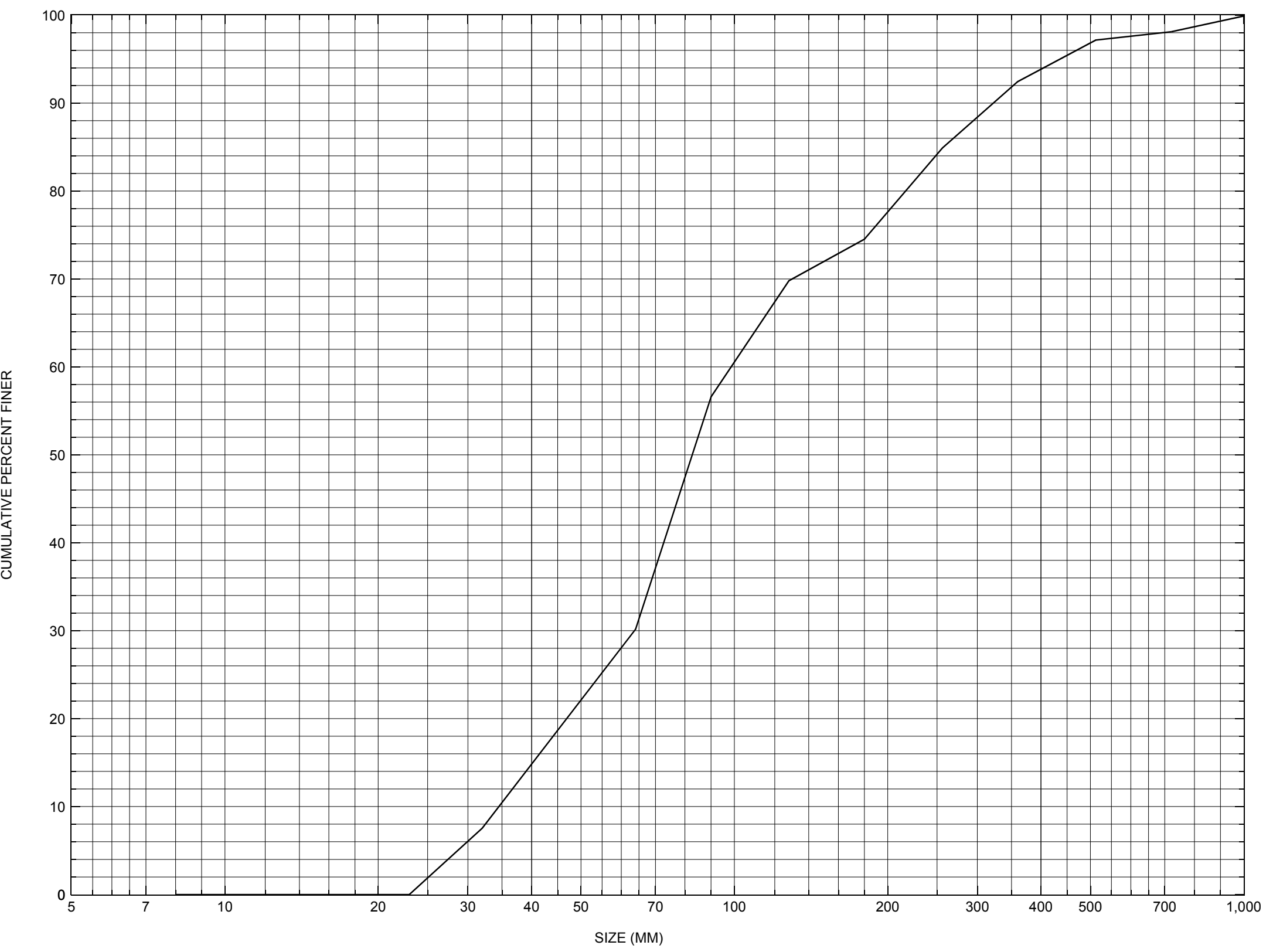

Appendix C. Bed material particle-size distribution for a pebble count in the channel approach of structure JAMATH00010026, in Jamaica, Vermont. 


\section{APPENDIX D: \\ HISTORICAL DATA FORM}




\section{Structure Number JAMATH00010026}

\section{General Location Descriptive}

Data collected by (First Initial, Full last name) $\mathbf{E}$. BOEHMLER

Date $(M M / D D / Y Y) \_\mathbf{0 3} / \underline{29} / \underline{95}$

Highway District Number $(I-2 ; n n) \underline{\mathbf{0 2}}$

Town (FIPS place code; I - 4; nnnnn) $\mathbf{3 6 1 7 5}$

Waterway (I - 6) BALL MOUNTAIN BROOK

Route Number TH001

Topographic Map Jamaica

Latitude (I - 16; nnnn.n) $\mathbf{4 3 0 5 3}$
County (FIPS county code; I - 3; nnn)

Mile marker (I - 11; nnn.nnn) $\mathbf{0 0 0 0 0 0}$

Road Name (I - 7): -

Vicinity (I - 9) AT JCT TH 1 \& TH 30

Hydrologic Unit Code: $\mathbf{0 1 0 8 0 1 0 7}$

Longitude (i - 17; nnnnn.n) $\mathbf{7 2 4 8 9}$

\section{Select Federal Inventory Codes}

FHWA Structure Number (I - 8) 10130900261309

Maintenance responsibility $(I-21 ; n n) \quad \mathbf{0 3}$

Year built (I - 27; YYYY) 1982

Average daily traffic, ADT (I - 29; nnnnnn) 000140

Year of ADT (I - 30; YY) $\mathbf{9 1}$

Opening skew to Roadway $(I-34 ; n n) \quad \mathbf{0 8}$

Operational status $(I-41 ; X) \quad \mathbf{A}$

Structure type (I - 43; nnn) $\mathbf{3 0 2}$

Approach span structure type $(I-44 ; n n n) \quad \mathbf{0 0 0}$

Number of spans (I - 45; nnn) $\underline{\mathbf{0 0 1}}$

Number of approach spans (I - 46; nnnn) $\mathbf{0 0 0 0}$

Comments:

The structural inspection report of 9/13/93 indicates a single span steel stringer type bridge with a concrete deck. The abutment walls and wingwalls are concrete. On the right abutment there are minor cracks reported in the older concrete of the abutment wall. The upstream end is reported as having an older section of concrete with a newer concrete facing. There is an older concrete footing noted exposed on the right abutment as well. The top of the older footing at the upstream end is about 2 feet higher than the adjacent streambed. The streambed is up to 9 inches below the bottom of this section of the footing just upstream of the newer footing. The top of the footing on the upstream (Continued, page 33) 


\section{Bridge Hydrologic Data}

Is there hydrologic data available? $\underline{\mathbf{Y}}$ if No, type ctrl- $n$ VTAOT Drainage area $\left(\mathrm{mi}^{2}\right): \underline{\mathbf{2 9 . 0}}$

Terrain character:

Stream character \& type: Mountainous, steep, and swift moving

Streambed material: cobbles

Discharge Data (cfs): $\quad Q_{2.33} 1900$

$\mathrm{Q}_{50} \mathbf{7 1 5 0}$

$\mathrm{Q}_{10} \frac{\mathbf{4 1 0 0}}{\mathbf{8 5 5 0}}$

$\mathrm{Q}_{25} \mathbf{5 7 0 0}$

$Q_{500}$

Record flood date $(M M / D D / Y Y)$ :

Water surface elevation $(f t):-$

Estimated Discharge (cfs): I

25

$(f t / s): \mathbf{1 3 . 5}$

Ice conditions (Heavy, Moderate, Light): Moderate Debris (Heavy, Moderate, Light): Moderate

The stage increases to maximum highwater elevation (Rapidly, Not rapidly): Rapidly

The stream response is (Flashy, Not flashy): Flashy

Describe any significant site conditions upstream or downstream that may influence the stream's stage: -

Watershed storage area (in percent):

The watershed storage area is: - (1-mainly at the headwaters; 2- uniformly distributed; 3-immediatly upstream oi the site)

Water Surface Elevation Estimates for Existing Structure:

\begin{tabular}{|l|l|c|c|l|l|}
\hline Peak discharge frequency & $Q_{2.33}$ & $Q_{10}$ & $Q_{25}$ & $Q_{50}$ & $Q_{100}$ \\
Water surface elevation (ft)) & $\mathbf{4 8 9 . 2}$ & $\mathbf{4 9 1 . 4}$ & $\mathbf{4 9 2 . 7}$ & $\mathbf{4 9 3 . 7}$ & $\mathbf{4 9 4 . 6}$ \\
Velocity $(\mathrm{ft} / \mathrm{sec})$ & - & - & $\mathbf{1 3 . 5}$ & - & - \\
\hline
\end{tabular}

Long term stream bed changes: -

Is the roadway overtopped below the $\mathrm{Q}_{100}$ ? (Yes, No, Unknown): $\mathbf{N} \quad$ Frequency: -

Relief Elevation $(f t)$ :

Discharge over roadway at $\mathrm{Q}_{100}\left(\mathrm{ft}^{3} / \mathrm{sec}\right)$ :

Are there other structures nearby? (Yes, No, Unknown): $\mathbf{Y}$ Upstream distance (miles): Town: If No or Unknown, type ctrl-n os Highway No. : Structure No. : Year Built:

Clear span (ft): Clear Height (ft): Full Waterway $\left(f^{2}\right)$ : 
Downstream distance (miles): Town: Jamaica

Highway No. : $\mathbf{\text { TH01 }}$ Structure No. : 25 Structure Type: Steel Stringer

Clear span $(f t): \underline{\mathbf{6 2 . 0}}$ Clear Height $(f t): \underline{\mathbf{6 . 0}}$ Full Waterway $\left(f^{2}\right): 372.0$

Comments:

right wingwall is reported exposed but not undermined. There is some cracking reported on the right abutment wall. The left abutment and its wingwalls are reported in "like new" condition. The waterway makes a slight bend into the crossing with all of the flow against the right abutment. The streambed consists of stone and boulders. On older photos, the right abutment had riprap in place along the front of it and the report indicates high water has swept the riprap away.

\section{USGS Watershed Data}

Watershed Hydrographic Data

Drainage area $(D A) \stackrel{29.29}{\mathrm{mi}^{2}}$ Lake and pond area $\lcm{\mathbf{0 . 0 3}}$ $\mathrm{mi}^{2}$

Watershed storage (ST) 0.1

Bridge site elevation 1023.6 $\%$

Main channel length 9.99 $\mathrm{ft}$ Headwater elevation 3940 $\mathrm{ft}$ 10\% channel length elevation $\mathbf{1 2 0 1}$ $\mathrm{ft} \quad 85 \%$ channel length elevation 2106 $\mathrm{ft}$

Main channel slope (S) $\mathbf{1 2 0 . 8 8} \mathrm{ft} / \mathrm{mi}$

Watershed Precipitation Data

Average site precipitation in Average headwater precipitation in

Maximum 2yr-24hr precipitation event $(124,2)$ in

Average seasonal snowfall (Sn) $\mathrm{ft}$ 


\section{Bridge Plan Data}

Are plans available? $\mathbf{Y} \quad$ If no, type ctrl-n $p / \quad$ Date issued for construction (MM / YYYY): / 1982

Project Number BRZ 1442(4)

Minimum channel bed elevation: $\underline{482.5}$

Low superstructure elevation: USLAB $\underline{499.95}$ DSLAB $\underline{499.81}$ USRAB $\underline{496.78}$ DSRAB $\underline{496.64}$

Benchmark location description:

TBM\#1: spike in root of a 15 inch beech tree elevation 500.0 located on the south edge of a gravel road which is at south side of bridge about 80 feet south of right abutment and 20 feet west of the centerline of the road over bridge. TBM\#2: spike in root of an 18 inch pine tree elevation 515.55 about 180 feet north of left abutment along center line of road over bridge and 80 feet west from extended centerline.

Reference Point (MSL, Arbitrary, Other): Arbitrary $\quad$ Datum (NAD27, NAD83, Other): Arbitrary Foundation Type: 1 (1-Spreadfooting; 2-Pile; 3- Gravity; 4-Unknown)

If 1: Footing Thickness $\mathbf{2 . 0} \quad$ Footing bottom elevation: $\underline{\mathbf{4 8 4 . 0}}$

If 2: Pile Type:___ (1-Wood; 2-Steel or metal; 3-Concrete) Approximate pile driven length:

If 3: Footing bottom elevation:

Is boring information available? $\mathbf{N}$ If no, type ctrl- $n$ bi Number of borings taken: _-

Foundation Material Type: $\mathbf{3}$ (1-regolith, 2-bedrock, 3-unknown)

Briefly describe material at foundation bottom elevation or around piles:

NO FOUNDATION MATERIAL INFORMATION.

Comments:

Other elevation points: 1 ) the point at the downstream right wingwall where it intersects the right abutment, elevation 500.8 and 2) at the downstream left wingwall where it intersects left abutment, elevation 504.04.

* Elevation is for the left abutment. The right abutment footing bottom elevation is unknown. 


\section{Cross-sectional Data}

Is cross-sectional data available? $\underline{\mathbf{Y}}$ If no, type ctrl-n xs

Source (FEMA, VTAOT, Other)? FEMA

Comments:

\begin{tabular}{|l|l|l|l|l|l|l|l|l|l|l|l|}
\hline Station & 176 & 177 & 192 & 210 & 227 & 245 & 251 & - & - & - & - \\
\hline Feature & LAB & - & - & - & - & - & RAB & - & - & - & - \\
\hline $\begin{array}{l}\text { Low cord } \\
\text { elevation }\end{array}$ & 1018.2 & 1018.2 & 1017.5 & 1016.7 & 1016.0 & 1015.2 & 1014.9 & - & - & - & - \\
\hline $\begin{array}{l}\text { Bed } \\
\text { elevation }\end{array}$ & - & 1012.3 & 1004.4 & 1000.9 & 999.7 & 1000.8 & 1003.8 & - & - & - & - \\
\hline $\begin{array}{l}\text { Low cord to } \\
\text { bed length }\end{array}$ & - & 5.9 & 13.1 & 15.8 & 16.3 & 14.4 & 11.1 & - & - & - & - \\
\hline Station & - & - & - & - & - & - & - & - & - & - & - \\
\hline Feature & - & - & - & - & - & - & - & - & - & - & - \\
\hline $\begin{array}{l}\text { Low cord } \\
\text { elevation }\end{array}$ & - & - & - & - & - & - & - & - & - & - & - \\
\hline $\begin{array}{l}\text { Bed } \\
\text { elevation }\end{array}$ & - & - & - & - & - & - & - & - & - & - & - \\
\hline $\begin{array}{l}\text { Low cord to } \\
\text { bed length }\end{array}$ & - & - & - & - & - & - & - & - & - & - & - \\
\hline
\end{tabular}

Source (FEMA, VTAOT, Other)?

Comments: -

\begin{tabular}{|l|l|l|l|l|l|l|l|l|l|l|l|}
\hline Station & - & - & - & - & - & - & - & - & - & - & - \\
\hline Feature & - & - & - & - & - & - & - & - & - & - & - \\
\hline $\begin{array}{l}\text { Low cord } \\
\text { elevation }\end{array}$ & - & - & - & - & - & - & - & - & - & - & - \\
\hline $\begin{array}{l}\text { Bed } \\
\text { elevation }\end{array}$ & - & - & - & - & - & - & - & - & - & - & - \\
\hline $\begin{array}{l}\text { Low cord to } \\
\text { bed length }\end{array}$ & - & - & - & - & - & - & - & - & - & - & - \\
\hline Station & - & - & - & - & - & - & - & - & - & - & - \\
\hline Feature & - & - & - & - & - & - & - & - & - & - & - \\
\hline $\begin{array}{l}\text { Low cord } \\
\text { elevation }\end{array}$ & - & - & - & - & - & - & - & - & - & - & - \\
\hline $\begin{array}{l}\text { Bed } \\
\text { elevation }\end{array}$ & - & - & - & - & - & - & - & - & - & - & - \\
\hline $\begin{array}{l}\text { Low cord to } \\
\text { bed length }\end{array}$ & - & - & - & - & - & - & - & - & - & - & - \\
\hline
\end{tabular}




\section{APPENDIX E: \\ LEVEL I DATA FORM}


U. S. Geological Survey

Bridge Field Data Collection and Processing Form

Qa/Qc Check by: $\underline{\mathbf{R B}}$ Date: $11 / 06 / 96$

\section{Structure Number JAMATH00010026}

Computerized by: $\underline{\mathbf{R B}}$ Date: 11/07/96

Reviewd by: $\quad$ RB Date: $\underline{05 / 05 / 97}$

\section{A. General Location Descriptive}

1. Data collected by (First Initial, Full last name) L. MEDALIE

2. Highway District Number $\mathbf{0 2}$

Mile marker $\mathbf{0 0 0 0}$

County WINDHAM (025)

Waterway ( $($ - 6) BALL MOUNTAIN BROOK

Town JAMAICA (36175)

Route Number TH01

Road Name -

3. Descriptive comments:

Hydrologic Unit Code: $\mathbf{0 1 0 8 0 1 0 7}$

Located at the junction of TH 1 and TH 30.

\section{B. Bridge Deck Observations}
4. Surface cover... LBUS 6
RBUS 6
LBDS 6
RBDS 6
Overall 6

(2b us, ds,lb,rb: 1- Urban; 2- Suburban; 3- Row crops; 4- Pasture; 5- Shrub- and brushland; 6- Forest; 7- Wetland)
5. Ambient water surface... US 2
UB 1
DS $\underline{2}$
(1- pool; 2- riffle)

6. Bridge structure type 1 (1- single span; 2- multiple span; 3- single arch; 4- multiple arch; 5-cylindrical culvert; 6- box culvert; or 7- other)
7. Bridge length $\underline{\mathbf{8 0}}$
(feet)
Span length $\mathbf{7 8}$
(feet)
Bridge width 29.3 (feet)

\section{Road approach to bridge:}
8. LB $\underline{2}$ RB $\underline{1}$
( 0 even, 1- lower, 2- higher)
9. LB_ RB 1
(1-Paved, 2- Not paved)

10. Embankment slope (run / rise in feet / foot):

US left 16:7:1

US right 11:8:1

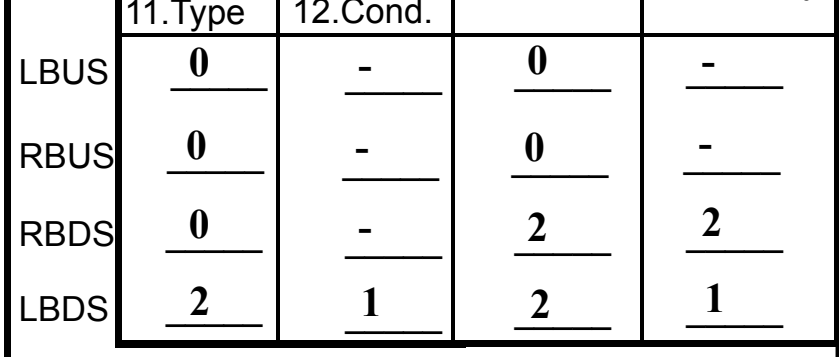

Bank protection types: 0 - none; 1- $<12$ inches; 2- $<36$ inches; $3-<48$ inches

4- < 60 inches; 5- wall / artificial levee

Bank protection conditions: 1- good; 2- slumped;

3- eroded; 4- failed

Erosion: 0 - none; 1- channel erosion; 2 -

road wash; 3- both; 4- other

Erosion Severity: 0 - none; 1- slight; 2- moderate; 3- severe

\section{Channel approach to bridge (BF):}

15. Angle of approach: $\mathbf{0}$

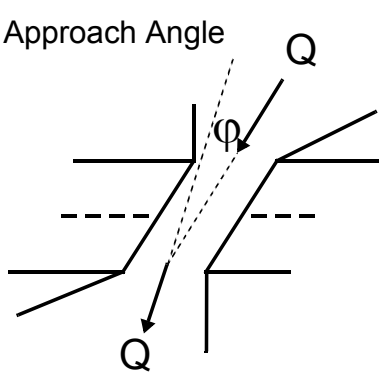

17. Channel impact zone 1 :

Where? RB (LB, RB)

Range? 198 feet $\underline{\text { US }}$

Channel impact zone 2:

Where? LB $(L B, R B)$

Range? 180 feet $\underline{\mathrm{DS}}$ (US, UB, DS) to $\underline{400}$ feet $\underline{\mathrm{DS}}$

Impact Severity: 0- none to very slight; 1-Slight; 2- Moderate; 3- Severe
16. Bridge skew: 10

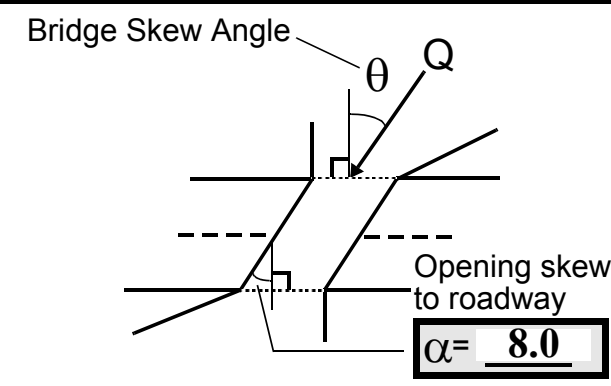

\section{Exist? $\mathbf{Y}(Y$ or $N)$}

Severity 1

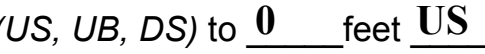

Exist? $\mathbf{Y}(\mathrm{Y}$ or $N)$

Severity 1

o roadway

$\alpha=$

(feet)


18. Bridge Type: $\mathbf{1 a / 3}$

1a- Vertical abutments with wingwalls

1 b- Vertical abutments without wingwalls

2- Vertical abutments and wingwalls, sloping embankment Wingwalls perpendicular to abut. face

3- Spill through abutments

4- Sloping embankment, vertical wingwalls and abutments

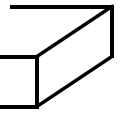

1a with wingwalls

Wingwall angle less than $90^{\circ}$.

19. Bridge Deck Comments (surface cover variations, measured bridge and span lengths, bridge type variations, approach overflow width, etc.)

5. The DS water surface is pooled to $25 \mathrm{ft}$. DS then it is riffled.

7. Values are from the VT AOT files. Measured bridge length is $79.5 \mathrm{ft}$., span length is $75.4 \mathrm{ft}$., and the bridge width is $29.6 \mathrm{ft}$.

14. The right bank DS road wash erosion is moderately severe because of the steep slope and loose material. The left bank DS road approach protection is an extension of the DS left wingwall protection around the end of the wingwall.

18. The wingwalls are all type 1a except the DS right wingwall which is type 4 . There is protection around the left abutment that creates a spill through slope.

\section{Upstream Channel Assessment}

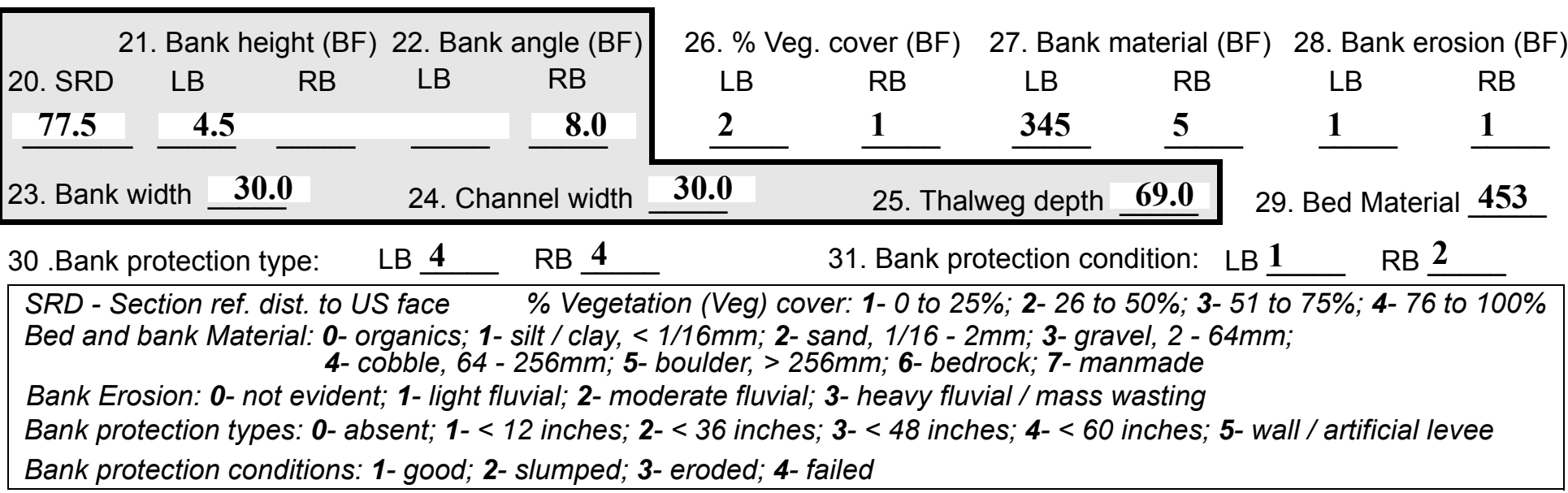

32. Comments (bank material variation, minor inflows, protection extent, etc.):

26. The right bank has minimal vegetation cover from the bridge till $154 \mathrm{ft}$. US, then it is type 4 . On the left bank, there is minimal vegetation cover from the bridge to $62 \mathrm{ft}$. US, then it is type 4 .

28. The right bank is an almost vertical wall of boulders built from the stream to be the road embankment for TH30.

30. The left bank protection extends from under the bridge to $29 \mathrm{ft}$. US. It is the same as the wingwall protection. The right bank protection extends from the end of the wingwall to $154 \mathrm{ft}$. US, though there is still mostly boulders in the bank beyond at least $100 \mathrm{ft}$. There is also type- 3 and type-2 protection along the banks. 
36. Point bar extent: $\underline{\mathbf{1 7 2}}$ feet $\underline{\text { US }}$ (US, UB) to $\underline{\mathbf{7 4}}$ feet $\underline{\mathrm{DS}}$ (US, UB, DS) positioned $\underline{\mathbf{0}} \%$ LB to $\underline{\mathbf{7 5}} \%$ RB

37. Material: $\mathbf{5 4 3}$

38. Point or side bar comments (Circle Point or Side; Note additional bars, material variation, status, etc.):

39. Is a cut-bank present? $\mathbf{Y}$ ( $Y$ or if $N$ type ctrl-n cb)

40. Where? $\underline{\mathbf{R B}}$ (LB or RB)

41. Mid-bank distance: 172

42. Cut bank extent: $\underline{\mathbf{2 0 0}}$ feet $\underline{\mathrm{US}}$ (US, UB) to $\underline{\mathbf{1 8}}$ feet $\underline{\mathbf{U S}}$ (US, UB, DS)

43. Bank damage: 2

(1- eroded and/or creep; 2- slip failure; 3- block failure)

44. Cut bank comments (eg. additional cut banks, protection condition, etc.):

The cut bank begins at the end of the US right wingwall.

45. Is channel scour present? $\mathbf{Y}$ ( $Y$ or if $N$ type ctrl-n cs)

47. Scour dimensions: Length 25

Width 6

Depth : 1

46. Mid-scour distance: $\mathbf{0}$

48. Scour comments (eg. additional scour areas, local scouring process, etc.):

There are also some minor local pockets of scour around large boulders.

\section{Are there major confluences? $\mathbf{Y}$ ( $Y$ or if $N$ type ctrl-n $m c$ ) \\ 51. Confluence 1: Distance $\mathbf{3 7 5}$ \\ 52. Enters on $\mathbf{R B} \quad(L B$ or $R B)$ \\ Confluence 2: Distance - \\ Enters on - (LB or $R B)$}

54. Confluence comments (eg. confluence name):

50. How many? 1

53. Type 2 (1- perennial; 2- ephemeral)

Type (1-perennial; 2- ephemeral)

-

55. Channel restraint (BF)? LB 2

\section{Under Bridge Channel Assessment}

\begin{tabular}{|c|c|c|c|c|c|c|c|c|}
\hline \multicolumn{2}{|c|}{ 56. Height (BF) } & \multicolumn{2}{|c|}{57 Angle (BF) } & \multicolumn{2}{|c|}{ 61. Material (BF) } & \multicolumn{2}{|c|}{ 62. Erosion (BF) } & \\
\hline LB & RB & LB & RB & LB & RB & LB & RB & \\
\hline 47 & & & & 2 & 7 & 7 & - & \\
\hline
\end{tabular}

63. Bed Material -

Bed and bank Material: 0- organics; 1- silt / clay, < 1/16mm; 2- sand, 1/16 - 2mm; 3- gravel, 2 - 64mm; 4- cobble, 64 - 256mm; 5- boulder, > 256mm; 6- bedrock; 7- manmade

Bank Erosion: 0- not evident; 1- light fluvial; 2- moderate fluvial; 3- heavy fluvial / mass wasting

64. Comments (bank material variation, minor inflows, protection extent, etc.):

453 
65. Debris and Ice Is there debris accumulation?

67. Debris Potential (1- Low; 2- Moderate; 3- High)

69. Is there evidence of ice build-up? 1

70. Debris and Ice Comments:
(Yor $N)$ 66. Where? $\mathbf{N}$

68. Capture Efficiency 2

(1- Upstream; 2- At bridge; 3- Both)

Ice Blockage Potential $\underline{\mathbf{N}}$
(1- Low; 2- Moderate; 3- High)

(1-Low; 2- Moderate; 3- High) 1

\begin{tabular}{|l|c|c|c|c|c|c|c|c|}
\hline Abutments & $\begin{array}{c}\text { 71. Attack } \\
\angle \text { (BF) }\end{array}$ & $\begin{array}{c}72 \text {. Slope } \angle \\
\text { (Qmax) }\end{array}$ & $\begin{array}{c}\text { 73. Toe } \\
\text { loc. (BF) }\end{array}$ & $\begin{array}{c}\text { 74. Scour } \\
\text { Condition }\end{array}$ & $\begin{array}{c}\text { 75. Scour } \\
\text { depth }\end{array}$ & $\begin{array}{c}\text { 76. Exposure } \\
\text { depth }\end{array}$ & 77. Material & 78. Length \\
\hline LABUT & & $\mathbf{0}$ & $\mathbf{9 0}$ & $\mathbf{0}$ & $\mathbf{0}$ & - & - & $\mathbf{9 0 . 0}$ \\
\hline RABUT & $\mathbf{1}$ & $\mathbf{5}$ & $\mathbf{9 0}$ & & & $\mathbf{2}$ & $\mathbf{3}$ & $\mathbf{7 4 . 5}$ \\
\hline
\end{tabular}

Pushed: $L B$ or RB

Toe Location (Loc.): 0- even, 1- set back, 2- protrudes

Scour cond.: 0- not evident; 1- evident (comment); 2- footing exposed; 3-undermined footing; 4- piling exposed; 5- settled; 6- failed

Materials: 1- Concrete; 2- Stone masonry or drywall; 3- steel or metal; 4- wood

79. Abutment comments (eg. undermined penetration, unusual scour processes, debris, etc.):

2

2

1

72. The concrete part of the left abutment is at 90 degrees, and the stone fill is at a 45 degree angle.

71. The attack angle on the right abutment is 30 degrees if considering the bend of the channel beyond $150 \mathrm{ft}$.

US. For the closest $150 \mathrm{ft}$. of the channel, the attack angle is 5 degrees.

On the right abutment, beginning at $11 \mathrm{ft}$. under the bridge from the DS bridge face and continuing around the DS right wingwall, the top of a concrete footing is flush with the channel bottom and extends $6.5 \mathrm{ft}$. into the channel. The scour depth and exposure depth given in \#75 and \#76 represent what is occurring at the US most $20 \mathrm{ft}$. of the right abutment. The exposure depth is measured from the top of the footing. Average thal-

80. Wingwalls:

Exist? Material? Scour Scour Exposure $\begin{aligned} & 81 . \\ & \text { Angle? Length? }\end{aligned}$ Condition? depth? depth?

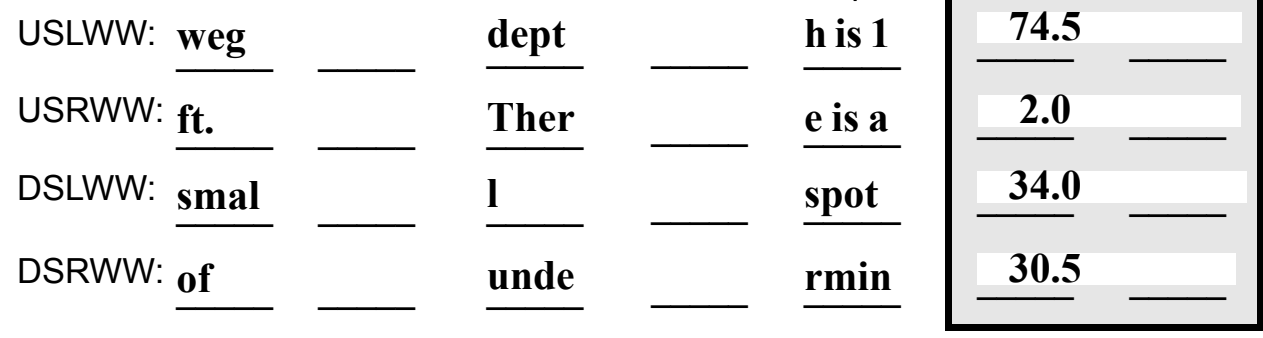

Wingwall materials: 1- Concrete; 2- Stone masonry or drywall; 3- steel or metal; 4- wood

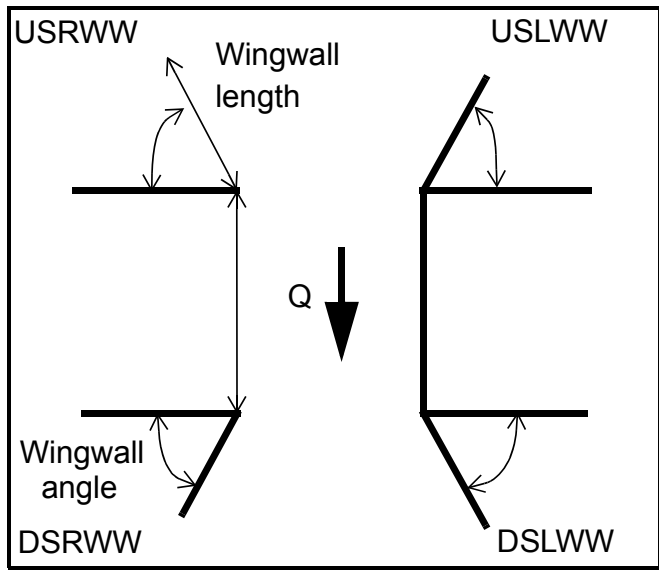

82. Bank / Bridge Protection:

\begin{tabular}{|l|l|l|l|l|l|l|l|l|}
\hline Location & USLWW & USRWW & LABUT & RABUT & LB & RB & DSLWW & DSRWW \\
\hline Type & ing & mid & und & brid & re it & sible & etra & in. \\
\hline Condition & abo & - & er & ge & is & to & te & \\
\hline Extent & ut & way & the & whe & pos- & pen- & $\mathbf{1 0}$ & Y \\
\hline
\end{tabular}

Bank / Bridge protection types: 0- absent; 1- < 12 inches; 2- < 36 inches; 3- < 48 inches; 4- < 60 inches; 
83. Wingwall and protection comments (eg. undermined penetration, unusual scour processes, etc.):

$\mathbf{1}$
$\mathbf{-}$
-
$\mathbf{Y}$
$\mathbf{1}$
$\mathbf{1}$
$\mathbf{1}$
$\mathbf{0}$
$\mathbf{Y}$
$\mathbf{1}$

Piers:

84. Are there piers? $\quad \mathbf{0}$ (Y or if $N$ type ctrl-n pr)

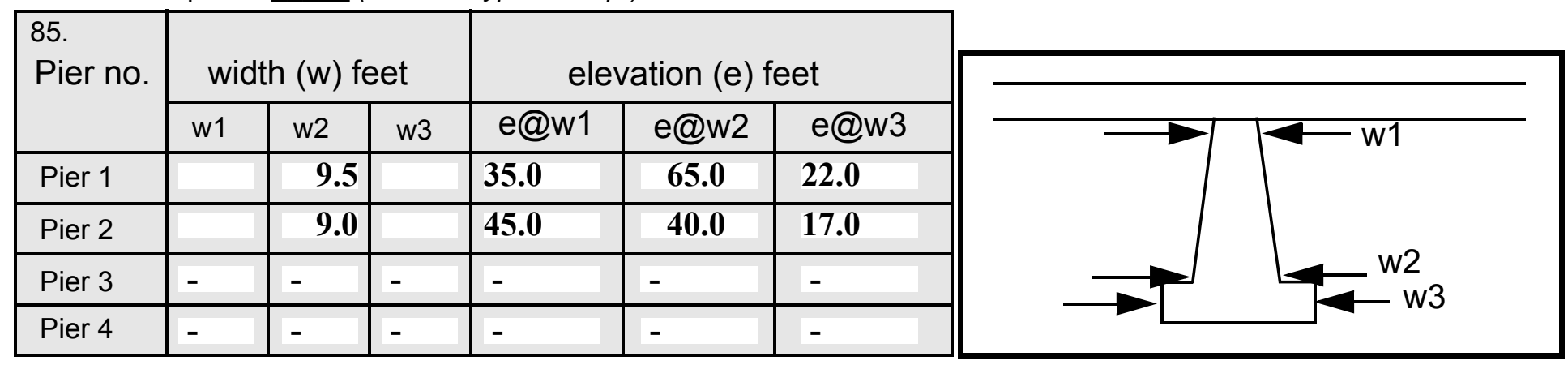

\begin{tabular}{|l|l|l|l|l|}
\hline Level 1 Pier Descr. & \multicolumn{1}{|c|}{1} & \multicolumn{1}{|c|}{2} & 3 & \multicolumn{1}{|c|}{4} \\
\hline 86. Location (BF) & - & 2 & - & placed \\
\hline 87. Type & - & 4 & 4 & to \\
\hline 88. Material & Y & $\mathbf{1}$ & $\mathbf{1}$ & pro- \\
\hline 89. Shape & $\mathbf{1}$ & $\mathbf{1}$ & $\mathbf{1}$ & tect \\
\hline 90. Inclined? & $\mathbf{1}$ & $\mathbf{0}$ & $\mathbf{0}$ & the \\
\hline 91. Attack $\angle$ (BF) & $\mathbf{1}$ & - & - & US \\
\hline 92. Pushed & $\mathbf{0}$ & - & - & end \\
\hline 93. Length (feet) & - & - & - & - \\
\hline 94. \# of piles & $\mathbf{4}$ & - & $\mathbf{8 2 .}$ & of \\
\hline 95. Cross-members & $\mathbf{1}$ & - & Ther & the \\
\hline 96. Scour Condition & $\mathbf{1}$ & - & e are & US \\
\hline 97. Scour depth & $\mathbf{3}$ & - & stone & right \\
\hline 98. Exposure depth & $\mathbf{1}$ & - & s & wing \\
\hline
\end{tabular}

LFP, LTB, LB, MCL, MCM, MCR, RB, RTB, RFP

1- Solid pier, 2- column, 3- bent

1-Wood; 2- concrete; 3- metal; 4- stone

1- Round; 2- Square; 3- Pointed

Y-yes; $N$ - no

$L B$ or $R B$

0- none; 1- laterals; 2- diagonals; 3- both

0- not evident; 1- evident (comment);

2- footing exposed; 3- piling exposed;

4- undermined footing; 5- settled; 6- failed 
99. Pier comments (eg. undermined penetration, protection and protection extent, unusual scour processes, etc.):

wall. The protection on the left abutment creates a spill through slope. There is also type-3 and type-2 protection in front of the US left wingwall.

80. Along the DS $12 \mathrm{ft}$. of the base of the US right wingwall there is a squared wooden horizontal beam, from which the top of the concrete footing extends $5 \mathrm{ft}$. into the channel and is flush with the channel bottom. The DS right wingwall footing is also flush with the channel bottom and only extends $4 \mathrm{ft}$. into the channel.

100.

\section{E. Downstream Channel Assessment}

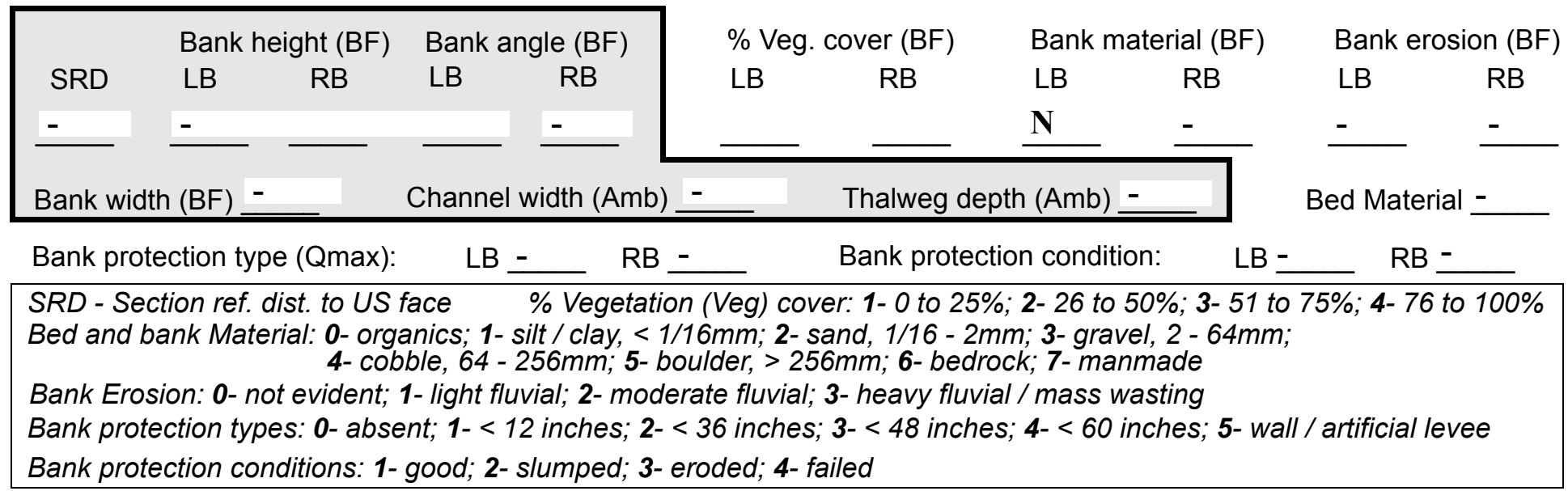

Comments (eg. bank material variation, minor inflows, protection extent, etc.):

$-$

$-$

$-$

-

-

-

-

-

-

\section{Is a drop structure present? _ ( $Y$ or $N$, if $N$ type ctrl-n ds) 102. Distance: _ _ feet}
103. Drop: - feet
104. Structure material: -
(1- steel sheet pile; 2- wood pile; 3-concrete; 4- other)

105. Drop structure comments (eg. downstream scour depth): 
106. Point/Side bar present? (Y or $N$. if $N$ type ctrl-n pb)Mid-bar distance:

Mid-bar width: -

Point bar extent: feet -

(US, UB, DS) to feet (US, UB, DS) positioned $\%$ LB to $\% \mathrm{RB}$ Material:

Point or side bar comments (Circle Point or Side; note additional bars, material variation, status, etc.):

\section{Is a cut-bank present? _ _ (Y or if $N$ type ctrl-n cb) Where? - (LB or $R B)$ \\ Mid-bank distance: -}

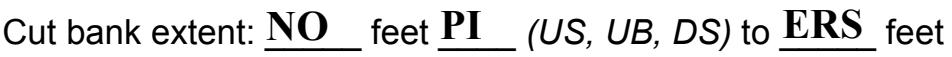
(US, UB, DS)

Bank damage: (1- eroded and/or creep; 2- slip failure; 3- block failure)

Cut bank comments (eg. additional cut banks, protection condition, etc.):

Is channel scour present? ( $Y$ or if $N$ type ctrl-n cs)

Mid-scour distance: Scour dimensions: Length Width 4 Depth: 1 Positioned $\underline{54} \%$ LB to $\underline{\mathbf{5 4}} \%$ RB Scour comments (eg. additional scour areas, local scouring process, etc.): 1 1 54 4

Are there major confluences? $\mathbf{0}$ ( $Y$ or if $N$ type ctrl-n $m c)$ Confluence 1: Distance Enters on The (LB or RB) Enters on tion (LB or RB)

Confluence 2: Distance eta-
How many? 1

Type veg- (1- perennial; 2- ephemeral)

Type cove (1- perennial; 2- ephemeral)

Confluence comments (eg. confluence name):

$r$ on the right bank is minimal until $73 \mathrm{ft}$. DS and then it is type 4. The left bank protection extends to $10 \mathrm{ft}$. DS. It is the same as the DS left wingwall protection.

\section{F. Geomorphic Channel Assessment}

107. Stage of reach evolution
1- Constructed

2- Stable

3- Aggraded

4- Degraded

5- Laterally unstable

6- Vertically and laterally unstable 
108. Evolution comments (Channel evolution not considering bridge effects; See HEC-20, Figure 1 for geomorphic descriptors): 


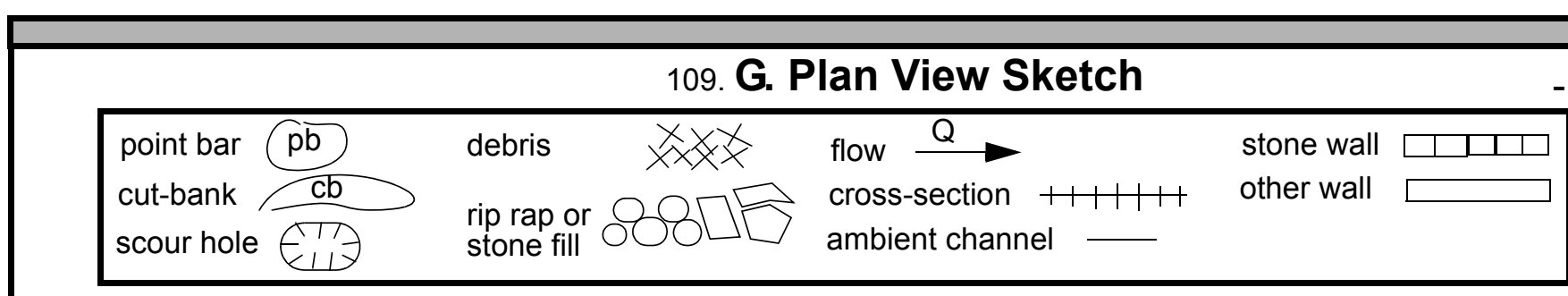


APPENDIX F:

SCOUR COMPUTATIONS 


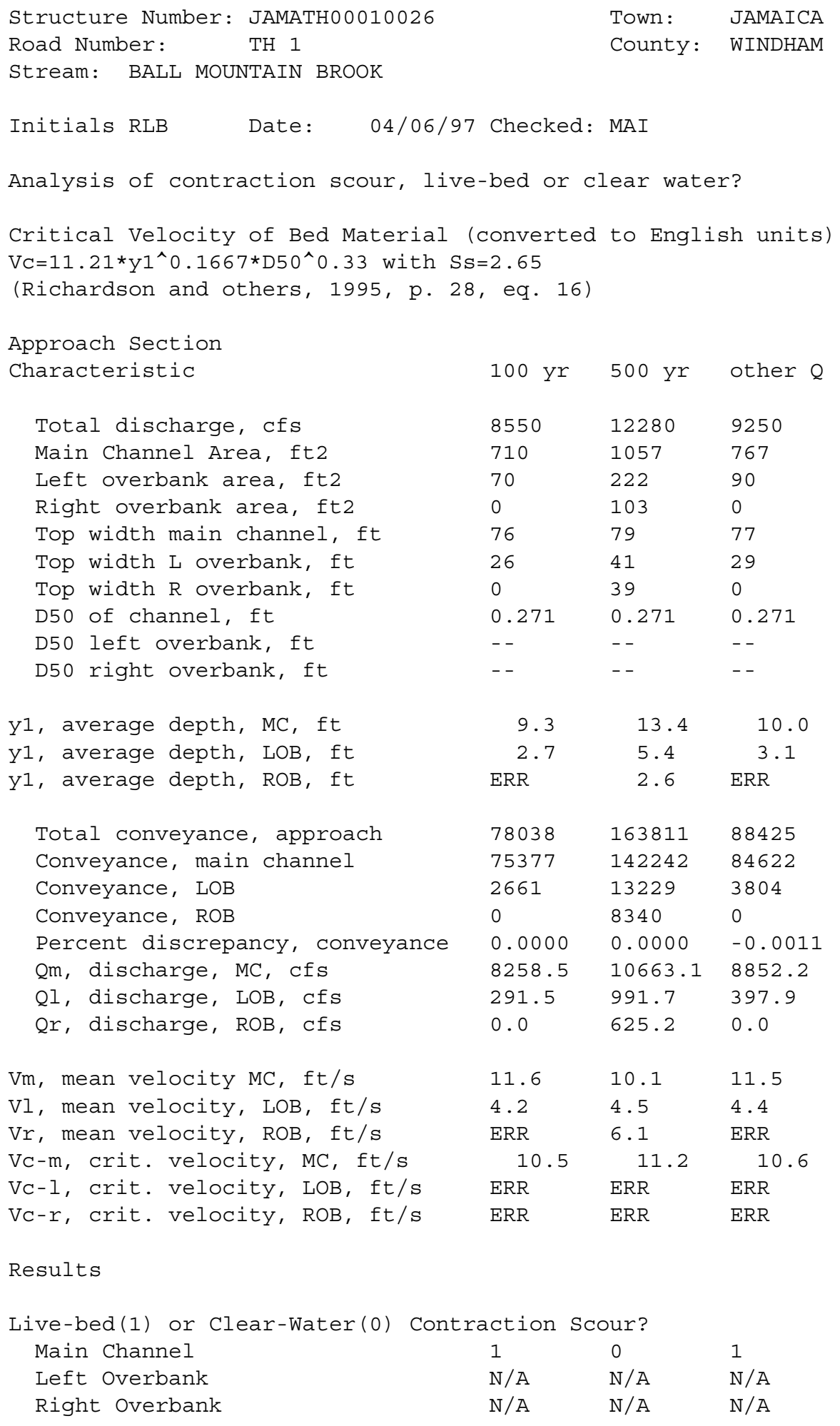




\begin{tabular}{|c|c|c|c|c|c|c|}
\hline \multicolumn{7}{|c|}{ 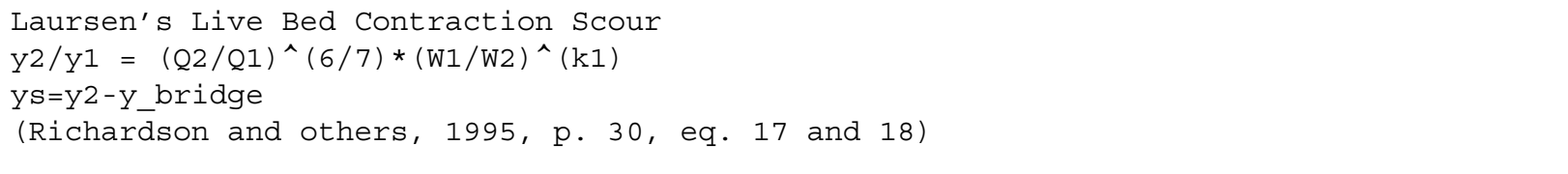 } \\
\hline & Approach & & & Bridge & & \\
\hline Characteristic & $100 \mathrm{yr}$ & $500 \mathrm{yr}$ & Other Q & $100 \mathrm{yr}$ & $500 \mathrm{yr}$ & Other Q \\
\hline Q1, discharge, cfs & 8550 & 12280 & 9250 & 8550 & 10652 & 9250 \\
\hline Total conveyance & 78038 & 163811 & 88425 & 49128 & 84022 & 51293 \\
\hline Main channel conveyance & 75377 & 142242 & 84622 & 49128 & 84022 & 51293 \\
\hline Main channel discharge & 8258 & 10663 & 8852 & 8550 & 10652 & 9250 \\
\hline Area - main channel, ft2 & 710 & 1057 & 767 & 557 & 926 & 574 \\
\hline (W1) channel width, ft & 76 & 79 & 77 & 63.9 & 66.1 & 64.2 \\
\hline (Wp) cumulative pier width, ft & 0 & 0 & 0 & 0 & 0 & 0 \\
\hline W1, adjusted bottom width(ft) & 76 & 79 & 77 & 63.9 & 66.1 & 64.2 \\
\hline D50, ft & 0.271 & 0.271 & 0.271 & & & \\
\hline w, fall velocity, ft/s (p. 32) & 4.26 & 4.26 & 4.26 & & & \\
\hline y, ave. depth flow, ft & 9.34 & 13.38 & 9.96 & 8.72 & 14.01 & 8.94 \\
\hline S1, slope EGL & 0.026 & 0.033 & 0.027 & & & \\
\hline $\mathrm{P}$, wetted perimeter, $\mathrm{MC}$, ft & 80 & 84 & 82 & & & \\
\hline R, hydraulic Radius, ft & 8.875 & 12.583 & 9.354 & & & \\
\hline V*, shear velocity, ft/s & 2.726 & 3.657 & 2.852 & & & \\
\hline $\mathrm{V} * / \mathrm{w}$ & 0.640 & 0.858 & 0.669 & & & \\
\hline $\begin{array}{l}\text { Bed transport coeff., } \mathrm{kl},(0.59 \mathrm{if} \\
\mathrm{kl}\end{array}$ & $\begin{array}{l}\mathrm{V} * / \mathrm{w}<0.5 \\
0.64\end{array}$ & $\begin{array}{l}0.64 \text { if } \\
0.64\end{array}$ & $\begin{array}{l}.5<\mathrm{V} * / \mathrm{W}<2 ; \\
0.64\end{array}$ & 0.69 if & $\mathrm{V} * / \mathrm{w}>2 . \mathrm{C}$ & $0 \mathrm{p} .33)$ \\
\hline $\mathrm{y}^{2}$, depth in contraction, ft & 10.75 & 14.98 & 11.62 & & & \\
\hline ys, scour depth, ft (y2-y_bridge & 2.04 & 0.97 & 2.68 & & & \\
\hline
\end{tabular}

Clear Water Contraction Scour in MAIN CHANNEL

$\mathrm{y}^{2}=\left(\mathrm{Q} 2^{\wedge} 2 /\left(131 * \mathrm{Dm}^{\wedge}(2 / 3) * \mathrm{~W} 2^{\wedge} 2\right)\right)^{\wedge}(3 / 7) \quad$ Converted to English Units

ys $=$ y2-y_bridge

(Richardson and others, 1995, p. 32, eq. 20, 20a)

$\begin{array}{llll}\text { Bridge Section } & \text { Q100 } & \text { Q500 } & \text { Other Q } \\ \text { (Q) total discharge, cfs } & 8550 & 12280 & 9250 \\ \text { (Q) discharge thru bridge, Cfs } & 8550 & 10652 & 9250 \\ \text { Main channel conveyance } & 49128 & 84022 & 51293 \\ \text { Total conveyance } & 49128 & 84022 & 51293 \\ \text { Q2, bridge MC discharge, cfs } & 8550 & 10652 & 9250 \\ \text { Main channel area, ft2 } & 557 & 926 & 574 \\ \text { Main channel width (normal), ft } & 63.9 & 66.1 & 64.2 \\ \text { Cum. width of piers in MC, ft } & 0.0 & 0.0 & 0.0\end{array}$


W, adjusted width, ft

$\begin{array}{lll}63.9 & 66.1 & 64.2 \\ 8.72 & 14.01 & 8.94 \\ 0.33875 & 0.33875 & 0.33875 \\ 11.21 & 13.15 & 11.94 \\ 2.49 & -0.86 & 3.00\end{array}$

ys, scour depth (y2-ybridge), ft $\quad 2.49 \quad-0.86 \quad 3.00$

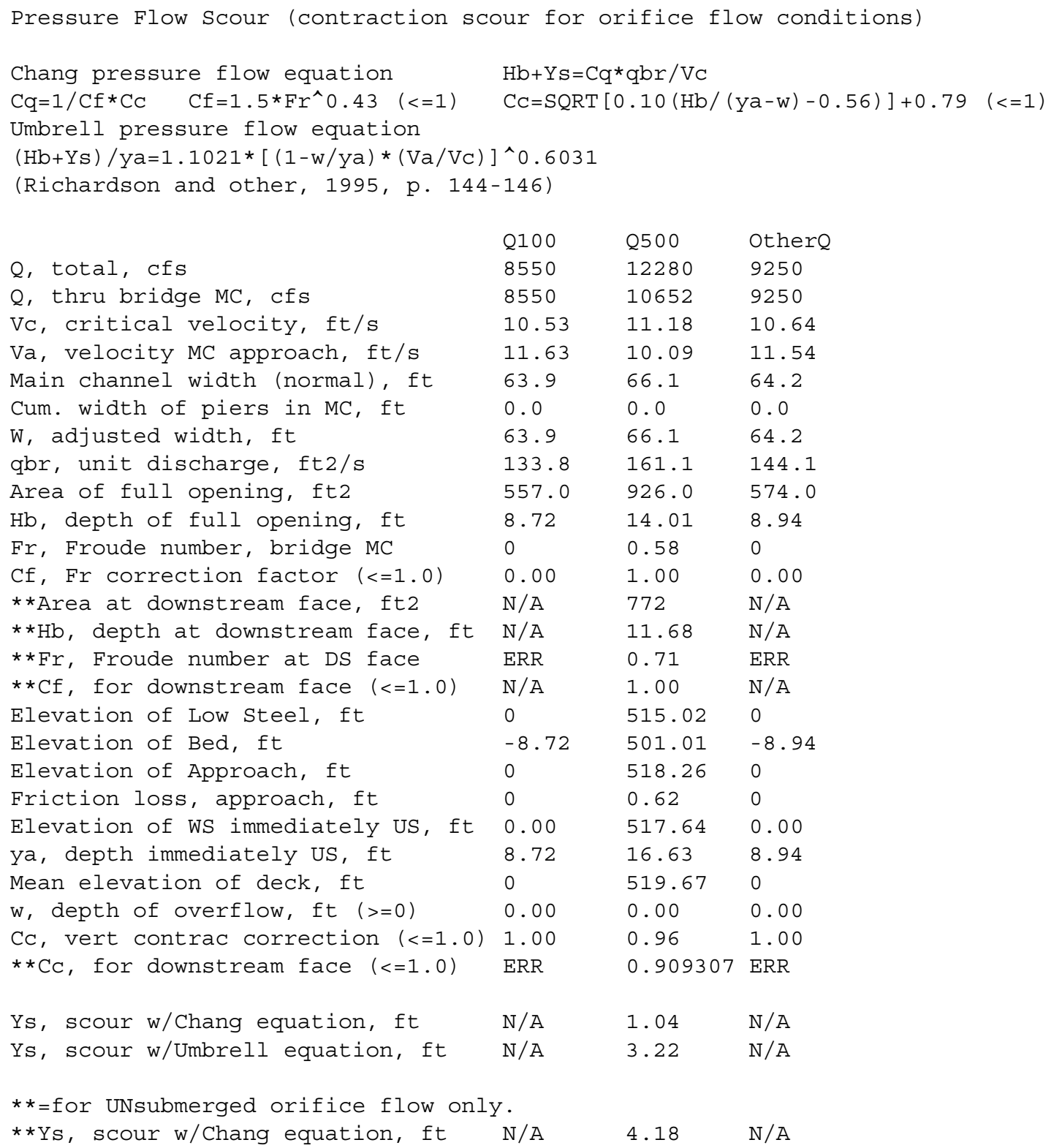




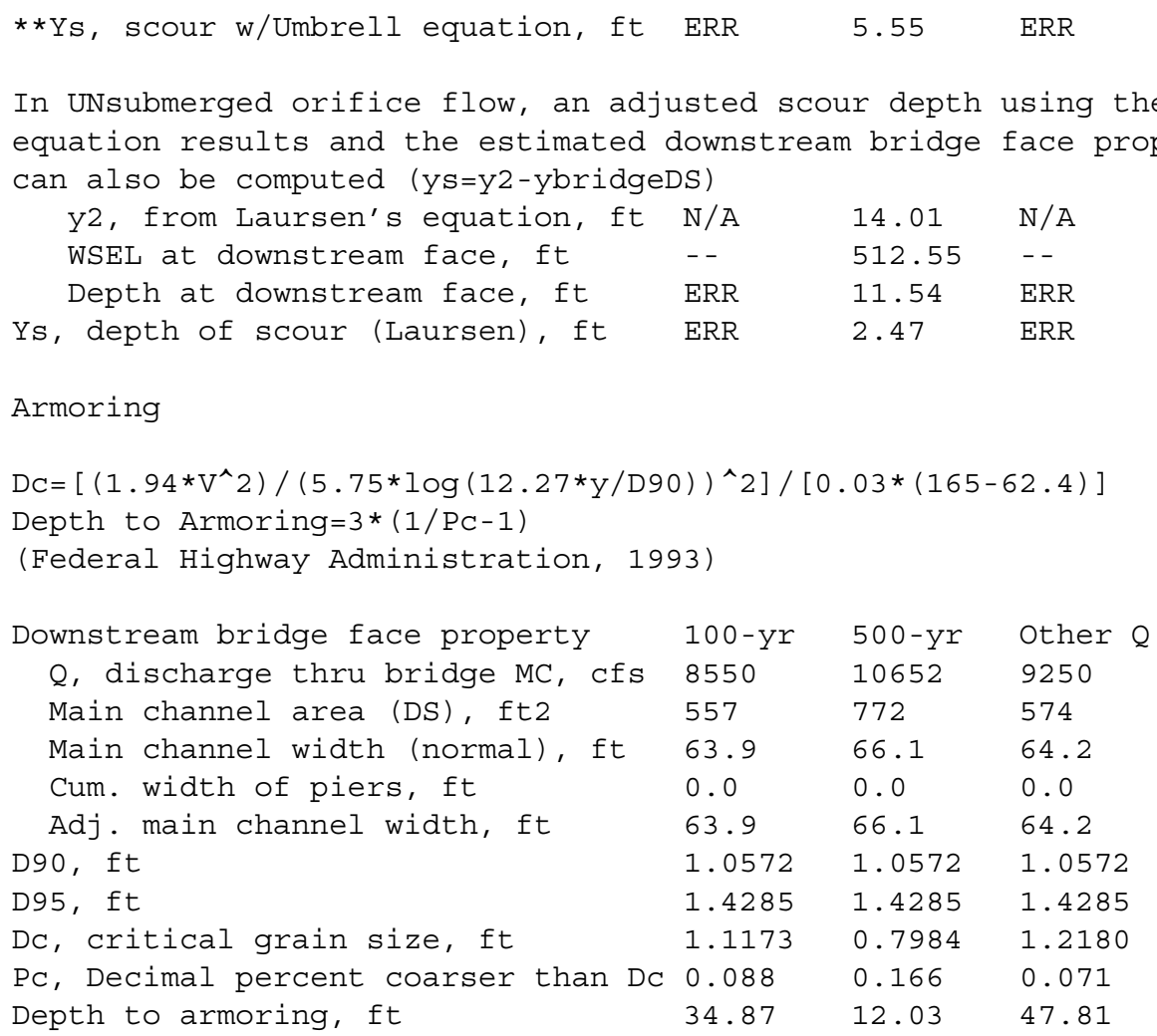

Abutment Scour

Froehlich's Abutment Scour

$\mathrm{Ys} / \mathrm{Y} 1=2.27 * \mathrm{~K} 1 * \mathrm{~K} 2 *\left(\mathrm{a}^{\prime} / \mathrm{Y} 1\right)^{\wedge} 0.43 * \mathrm{Fr} 1 \wedge 0.61+1$

(Richardson and others, 1995, p. 48, eq. 28)

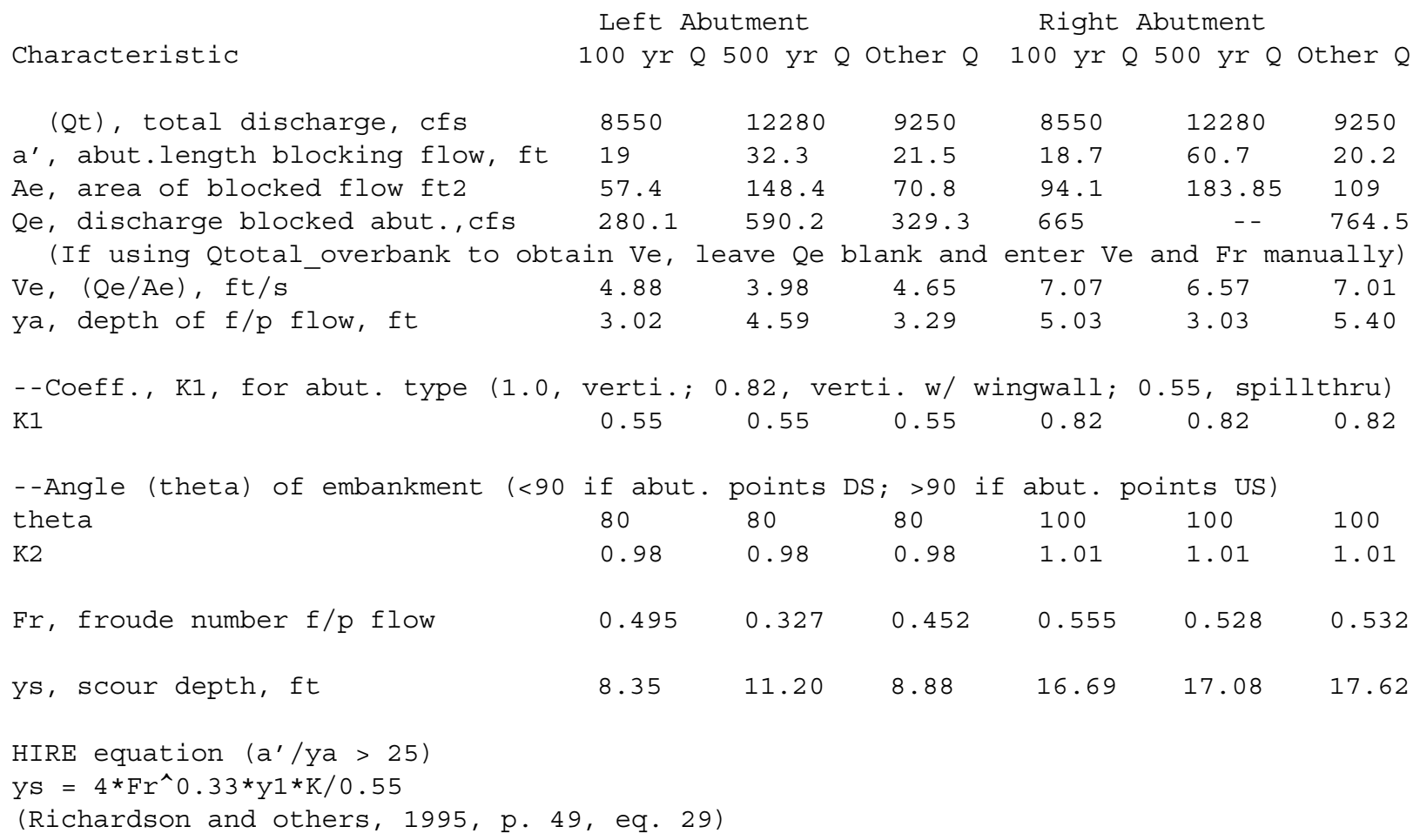




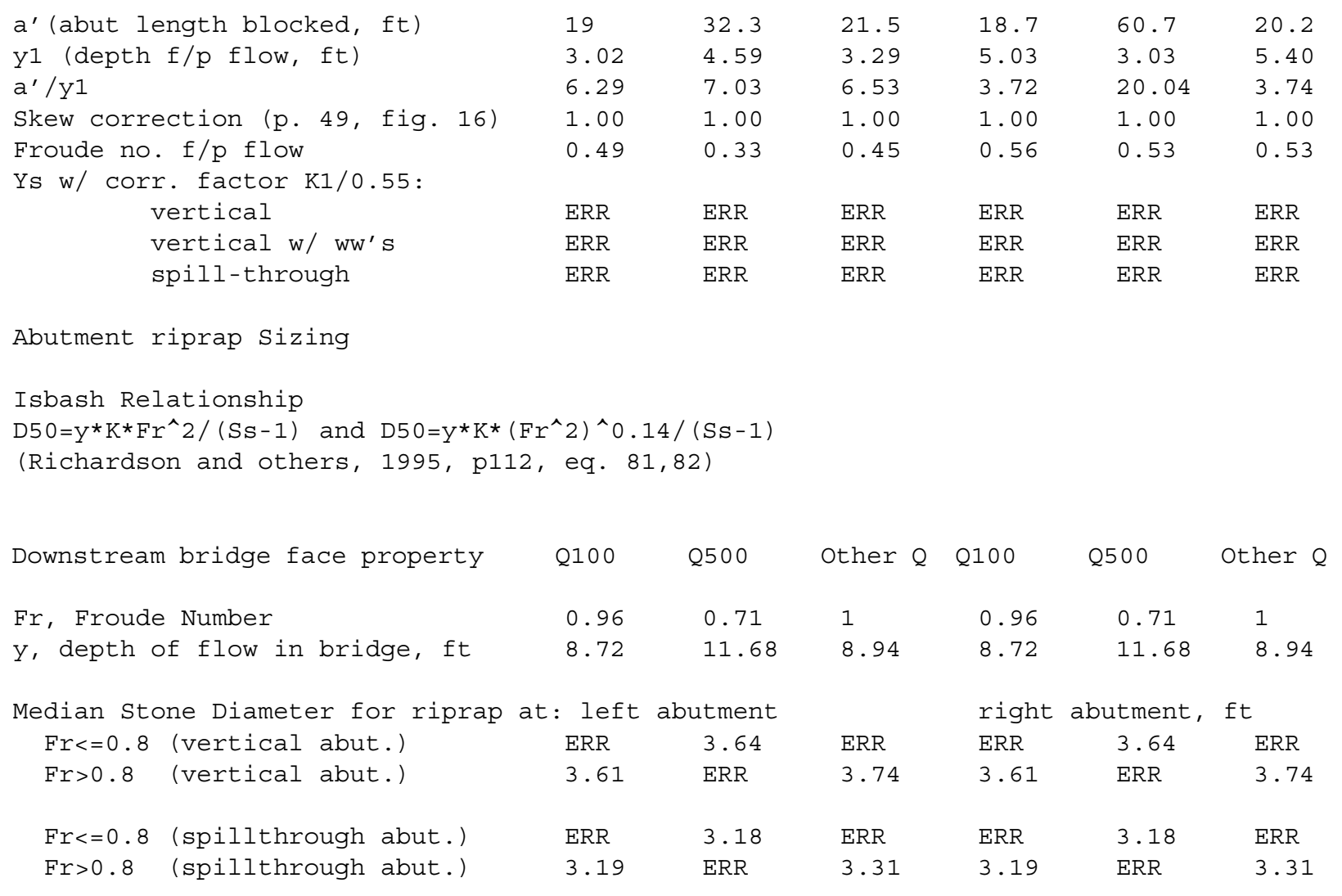


